\title{
Mycosporine-Like Amino Acids from Red Macroalgae: UV-Photoprotectors with Potential Cosmeceutical Applications
}

\author{
Julia Vega ${ }^{1, *(\mathbb{D}}$, Geniane Schneider ${ }^{2}$, Bruna R. Moreira ${ }^{2} \mathbb{C}$, Carolina Herrera ${ }^{2}$, José Bonomi-Barufi ${ }^{2} \mathbb{C}$ \\ and Félix L. Figueroa ${ }^{1}$ (D) \\ 1 Instituto Universitario de Biotecnología y Desarrollo Azul (IBYDA), Universidad de Málaga, \\ Departamento de Ecología, Campus Universitario de Teatinos s/n, 29071 Málaga, Spain; \\ felixlfigueroa@uma.es \\ 2 Phycology Laboratory, Botany Department, Federal University of Santa Catarina, Florianopolis 88049-900, \\ SC, Brazil; geniane.tega@gmail.com (G.S.); bruna.rm01@gmail.com (B.R.M.); chm.udea@gmail.com (C.H.); \\ jose.bonomi@ufsc.br (J.B.-B.) \\ * Correspondence: juliavega@uma.es
}

\section{check for} updates

Citation: Vega, J.; Schneider, G.; Moreira, B.R.; Herrera, C.;

Bonomi-Barufi, J.; Figueroa, F.L.

Mycosporine-Like Amino Acids from Red Macroalgae: UV-Photoprotectors with Potential Cosmeceutical Applications. Appl. Sci. 2021, 11, 5112. https://doi.org/10.3390/ app11115112

Academic Editors: Marco F. L. Lemos, Sara Novais and Carina Félix

Received: 19 April 2021

Accepted: 26 May 2021

Published: 31 May 2021

Publisher's Note: MDPI stays neutral with regard to jurisdictional claims in published maps and institutional affiliations.

Copyright: (c) 2021 by the authors. Licensee MDPI, Basel, Switzerland. This article is an open access article distributed under the terms and conditions of the Creative Commons Attribution (CC BY) license (https:// creativecommons.org/licenses/by/ $4.0 /)$.

\begin{abstract}
Macroalgae belong to a diverse group of organisms that could be exploited for biomolecule application. Among the biocompounds found in this group, mycosporine-like amino acids (MAAs) are highlighted mainly due to their photoprotection, antioxidant properties, and high photo and thermo-stability, which are attractive characteristics for the development of cosmeceutical products. Therefore, here we revise published data about MAAs, including their biosynthesis, biomass production, extraction, characterization, identification, purification, and bioactivities. MAAs can be found in many algae species, but the highest concentrations are found in red macroalgae, mainly in the order Bangiales, as Porphyra spp. In addition to the species, the content of MAAs can vary depending on environmental factors, of which solar radiation and nitrogen availability are the most influential. MAAs can confer photoprotection due to their capacity to absorb ultraviolet radiation or reduce the impact of free radicals on cells, among other properties. To extract these compounds, different approaches can be used. The efficiency of these methods can be evaluated with characterization and identification using high performance liquid chromatography (HPLC), associated with other apparatus such as mass spectrometry (MS) and nuclear magnetic resonance (NMR). Therefore, the data presented in this review allow a broad comprehension of MAAs and show perspectives for their inclusion in cosmeceutical products.
\end{abstract}

Keywords: antioxidants; cosmeceutic; extractions; integrated multitrophic aquaculture (IMTA); mycosporine-like amino acids (MAAs); purification; red macroalgae

\section{Introduction}

In recent decades, macroalgae have attracted significant biotechnological interest due to their wide biochemical composition (e.g., polysaccharides, fatty acids, carotenoids, phycobiliproteins, or mycosporine-like amino acids) with diverse potential bioactivities (e.g., antioxidant, anti-inflammatory, or photoprotective activities) [1]. Algae biomass can be used for different applications: (1) human consumption or feed due to its high nutritional value; (2) food additives due to its phycocolloid content; (3) biostimulants for plants due to algal growth-stimulating compounds; (4) cosmeceutical, nutraceutical, or pharmaceutical products due to its antioxidant, anti-inflammatory, or photoprotective properties $[2,3]$. This review is focused on the cosmeceutical applications of marine red macroalgae (Rhodophyta), and particularly on their use as natural ultraviolet (UV) filters due to their antioxidant and photoprotective capacity. The cosmetic industry is growing at a global scale and it is seeking innovations such as natural active principles. In recent decades, consumers have also tended to prefer natural products rather than synthetic 
ones, because the former look better, are safer, and are more beneficial for health and the environment.

UV radiation (UVR) that reaches the Earth's surface ( $<10 \%$ of the total received) is composed mainly of UV-A (320-400 nm) and a small portion of UV-B (290-320 nm). UV-B is the most dangerous, causing DNA mutations such as cyclobutane pyrimidine dimers (CPDs) or 6-4 photoproducts (6-4PP), which can be associated with cancer cell development. UV-A is considered less harmful, but can produce reactive oxygen species (ROS), altering the expression of certain genes related to premature skin aging [4-6]. Sunscreens are composed by different UV filters that protect the skin from exposure to UVR. UV filters are normally classified as: (1) synthetic or organic, based on the capacity to absorb UVR (e.g., octocrylene, butyl methoxydibenzoylmethane, oxybenzone); and (2) physical or inorganic, which can reflect the UVR (e.g., titanium dioxide). These filters have been found in different aquatic environments [7-9] associated with marine organisms such as mussels, fish or mammals $[10,11]$. Their presence can provoke negative effects such as inhibition of growth in phytoplankton [12], endocrine disruptions in fish [13,14] or stimulus of coral bleaching [15-17]. Different studies have also reported their negative effects in humans, such as in photoallergies or hormone disorders $[18,19]$. Thus, it is necessary to develop natural atoxic and biodegradable photoprotectors.

Mycosporine-like amino acids (MAAs) are secondary metabolites, mainly implicated in photoprotection, and produced by various organisms (algae or corals), of which red macroalgae are one of the main producers [20,21]. MAAs are a diverse group of nitrogenous compounds with low molecular weight $(<400 \mathrm{Da})$, and are colorless, uncharged, and water soluble. More than 30 types have been identified. All MAAs share the same central structure, a cychlohexenone or cyclohexenimine ring, responsible for the UV absorption. The different types of MAAs vary according to their nitrogen substituent (amino acid or its imino alcohol) in the chromophore, which determines their specific absorption spectra [22,23] (Figure 1). Different pathways have been proposed for its synthesis: (1) Firstly, the shikimate pathway was suggested [24-26]. The production of MAAs was inhibited in the coral Stylophora pistillata using glyphosate, an inhibitor of the shikimate pathway [25]. (2) More recently, the pentose-phosphate pathway was also demonstrated to be implicated in MAA biosynthesis [27-30]. Balskus and Walsh [27] found that a fourgene cluster linked to the pentose-phosphate pathway in Trichormus variabilis (previously known as Anabaena variabilis) was able to produce the MAA shinorine when inserted into Escherichia coli. However, Spence et al. [31] showed that this is not the major route of MAA synthesis. T. variabilis, with a deletion of the gene that encodes EVS (a key gene in the pentose phosphate pathway), still produces shinorine at levels of UV exposure. In recent years, some authors proposed that both pathways can be linked [32,33]. A deletion of the OMT gene (linked to the pentose phosphate pathway) in T. variabilis completely prevented shinorine synthesis, revealing that this gene product is essential to both pathways [32]. This evidence suggested that the shikimate pathway can be predominant for UV-induced MAA biosynthesis, whereas the pentose phosphate pathway can be used for the conservative production of MAAs. 


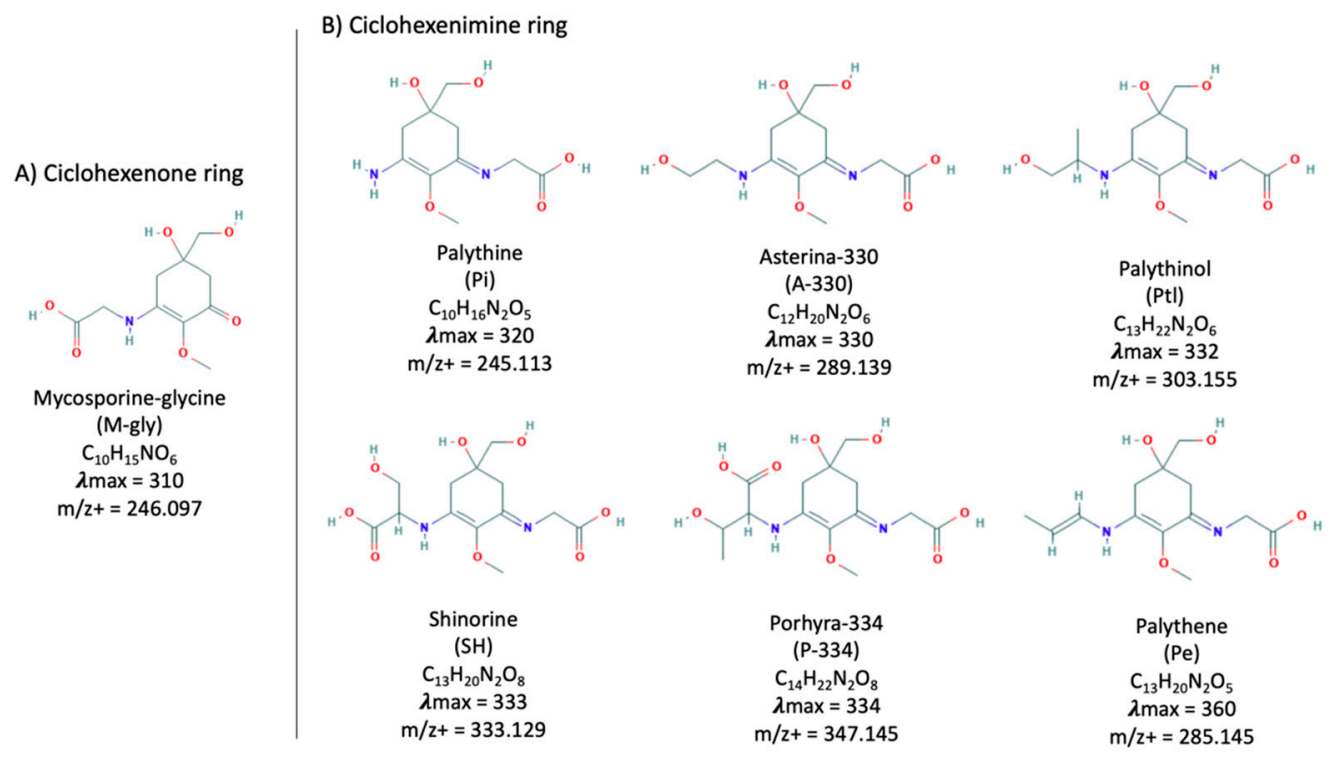

Figure 1. Chemical structure of the most common MAAs found in red macroalgae $[20,21,34-40]$.

Different characteristics and bioactivities have been attributed to MAAs that make them good candidates for cosmeceutical applications such as biological photoprotectors. These molecules are good UV-absorbing compounds with low toxicity, and high stability and antioxidant activity, among others (potential bioactivities are reviewed in Section 7) $[2,23,41]$.

This review describes the possible use of MAAs as biological photoprotectors for cosmeceutical applications, covering the different steps of the process: the screening of species with relevant bioactive compounds; the factors involved in the MAA productivity; the harvesting/culture of the biomass; the extraction, quantification, characterization, and purification of MAAs; and their different bioactivities (Figure 2). The information/data used in this review was obtained from different search engines (mainly Google Scholar) using keywords such as: UV-screen, antioxidant, macroalgae, photoprotection or culture. The most reliable information was obtained from research undertaken during the past 20 years (2000-2020).

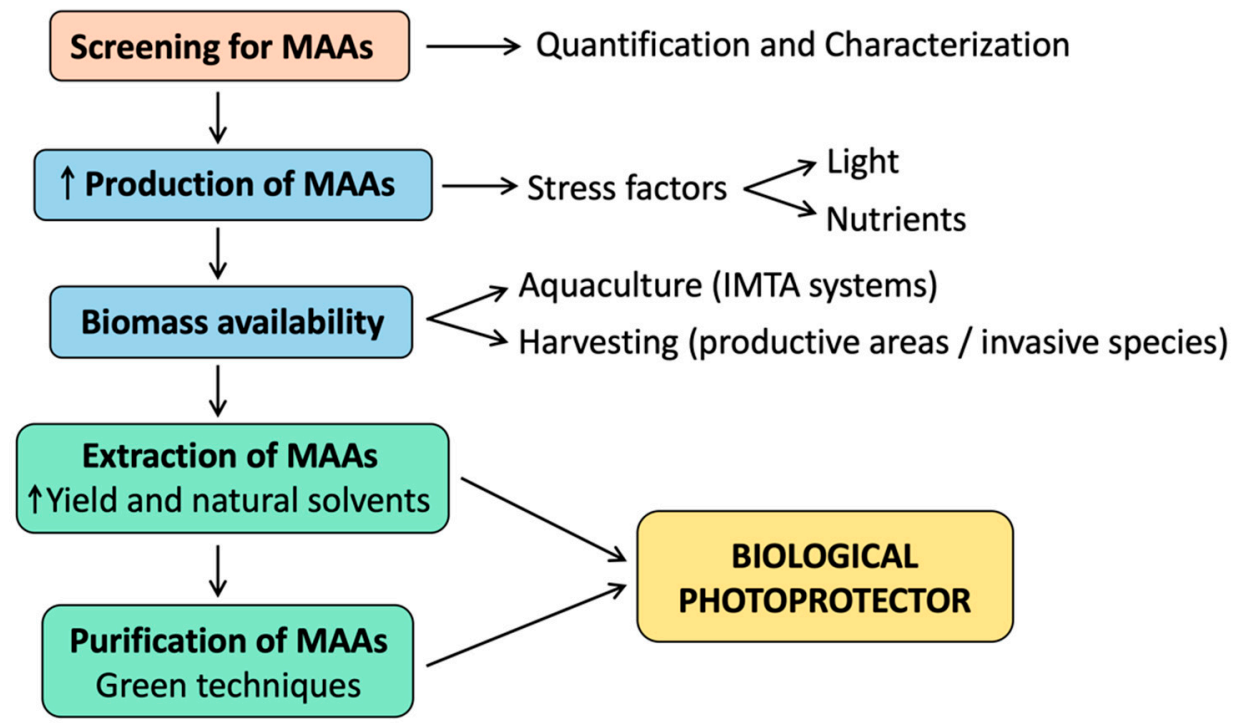

Figure 2. Scheme of the different steps of the process described in this review, involving screening, production, extraction, and purification. 


\section{Screening of MAAs}

Several authors studied the presence/concentration of MAAs in different red algae species and its geographical or seasonal variations. Navarro et al. [2] summarized in a book chapter the MAA content of different species from different geographic locations: Huovinen et al. [42] studied the MAA concentration in macroalgae from southern Chile, obtaining the highest content in Pyropia columbina (previously, Porphyra columbina) (7.2-10.6 $\left.\mathrm{mg} \mathrm{g}^{-1} \mathrm{DW}\right)$, followed by Bostrychia sp. (4.7 $\left.\mathrm{mg} \mathrm{g}^{-1} \mathrm{DW}\right)$, Gelidium sp. (2.2-6.8 $\mathrm{mg} \mathrm{g}^{-1}$ DW), and Mazzaella laminarioides (2.1-4.8 $\left.\mathrm{mg} \mathrm{g}^{-1} \mathrm{DW}\right)$. Briani et al. [43] studied macroalgae from the Brazilian coast and also obtained the highest MAA content in the genus Porphyra (Pyropia acanthophora, 5.2-6.6 $\mathrm{mg} \mathrm{g}^{-1} \mathrm{DW}$ ), followed by Laurencia caraibica (2.2-3.6 $\mathrm{mg}$ $\left.\mathrm{g}^{-1} \mathrm{DW}\right)$. Karsten et al. [44] studied different species found in tropical mangroves and observed a high content in species from the genus Bostrychia (3-12 $\left.\mathrm{mg} \mathrm{g}^{-1} \mathrm{DW}\right)$ and Stictosiphonia (6 $\left.\mathrm{mg} \mathrm{g}^{-1} \mathrm{DW}\right)$. More recently, Lalegerie et al. [45] analyzed the photoprotective compounds in several red algae species from Britanny (France), obtaining the highest concentrations in Bostrychia scorpioides, Porphyra dioica, Agarophyton vermiculophyllum (as Gracilaria vermicullophylla) and Vertebrata lanosa. The MAA content of species from southern Spain was also analyzed, obtaining high values in Porphyra umbilicalis (2.6-10 mg $\mathrm{g}^{-1} \mathrm{DW}$ ) and Bangia atropurpurea ( $\left.5 \mathrm{mg} \mathrm{g}^{-1} \mathrm{DW}\right)$, followed by Feldmannophycus rayssiae, Chondracanthus acicularis, Gelidium sp. and Osmundea pinnatifida $\left(1.5-3 \mathrm{mg} \mathrm{g}^{-1} \mathrm{DW}\right)$ [46-48].

Seasonal variation of MAAs has been reported in red macroalgae. A. vermicullophyllum from "Ria de Aveiro" (Portugal) showed a high MAA content in spring, due to the nitrogen (N)-enriched waters [49]. Guihéneuf et al. [50] observed an increase in the MAA content of different red algae (Palmaria palmata, Chondrus crispus, and P. dioica) in spring, induced by the increasing daily light and irradiance. Lalegerie et al. [51] also observed a high seasonal variability in P. palmata, with a higher content of MAAs in April and May, due to the light increase. In addition, short-term variation has been also reported (hourly and daily variations) [52-54]. For example, under days with ozone depletions in Patagonian, a rapid increase in myc-glycine was detected in P. columbina [53].

Korbee-Peinado [55] analyzed species from different orders and observed some patterns in the MAA content: the highest values were observed in Bangiales (Porphyra spp. and Bangia sp.), followed by Bonnemaisonales (Asparagopsis spp.) and Gelidialies (Gelidium sp.), whereas the lowest content was observed in Corallinales. Rhodophyta algae can be classified into three groups according to the concentration of MAAs: (1) species without the capacity to synthetize MAAs or with very low content of MAAs $\left(<1 \mathrm{mg} \mathrm{g}^{-1} \mathrm{DW}\right)$ (e.g., Corallinales or Plocamiales); (2) species with low content of MAAs (1-2 $\left.\mathrm{mg} \mathrm{g}^{-1} \mathrm{DW}\right)$ (e.g., Rhodymeniales or Ceramiales); and (3) species with a high content of MAAs ( $>2 \mathrm{mg} \mathrm{g}^{-1}$ DW) (e.g., Bangiales, Gelidiales, Gracilariales) [21,56]. In most cases, the quantity and quality of MAAs can vary depending on the environmental factors [57-60]. Within these orders, some species stand out, such as Porphyra spp., B. atropurpurea (Bangiales), and Gelidium pusillum (Gelidiales) [55].

Some authors published databases of MAAs. Sinha et al. [20] summarized the MAA data obtained in fungi, cyanobacteria, phytoplankton, macroalgae, and animals. More recently, Sun et al. [21] collected the MAA values observed in marine macroalgae over the past 30 years (1990-2019), and confirmed that 572 species of marine macroalgae contained MAAs (45 species of Chlorophyta, 41 species of Phaeophyceans, and 486 species of Rhodophyta). In this review, we analyzed the MAA values of the different red algae species obtained in previous articles $[2,42,43,45,47]$ and observed the pattern shown in Figure 3, in which the order Bangiales presented the highest MAA content, followed by Gracilariales and Ceramiales; the lowest MAA content was observed in the orders Corallinales, Rhodymeniales, Nemaliales, and Plocamiales. 


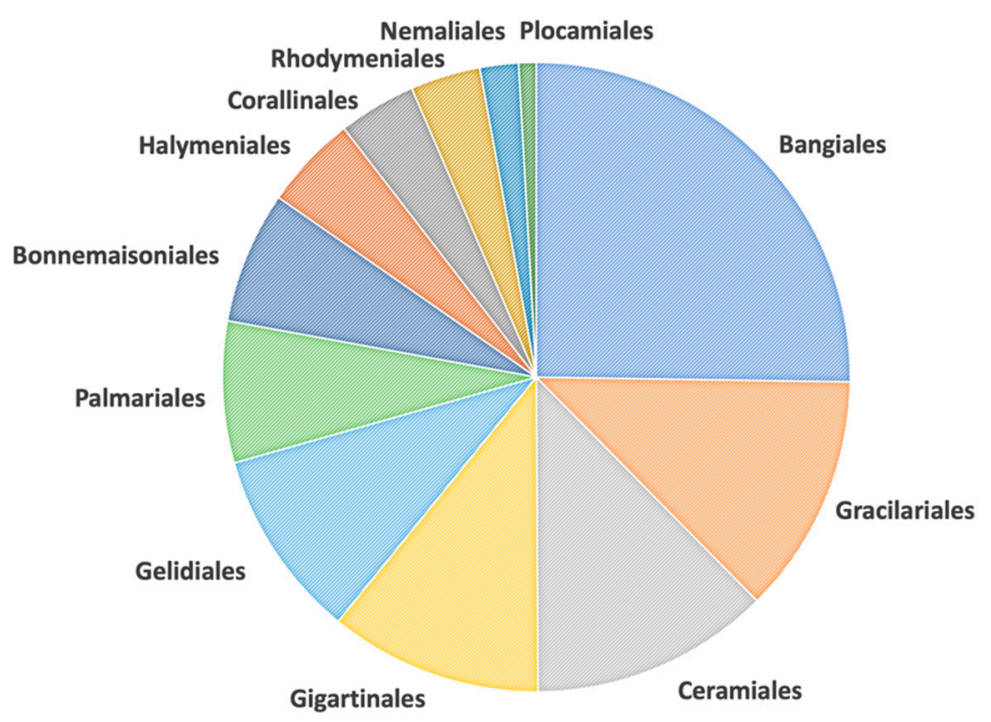

Figure 3. Distribution of MAAs in different orders of red macroalgae, according to the values obtained in previous studies $[2,42,43,45,47]$.

\section{Regulation of MAA Biosynthesis}

It is well known that the diversity and concentration of MAAs can vary, depending on environmental factors or culture conditions, such as radiation (PAR and UV), temperature, salinity, nutrients, $\mathrm{pH}$, or desiccation. The main factors involved in MAA biosynthesis are radiation (PAR and UV) and inorganic $\mathrm{N}$ availability [51,61-67].

PAR and mainly UVR are key factors in the induction of MAA production. Karsten et al. [68] observed that algae exposed to sunlight had 2.5-fold more MAA content than shaded species. Different authors studied the effect of quality and intensity of PAR and UVR in the synthesis of the different MAAs [67,69]. In C. crispus, the MAA palythine was synthesized under blue and white light. In the same study, pre-exposure to blue light followed by growth in UV-A increased the synthesis of shinorine seven-fold compared to treatments without previous exposure to blue light [70]. MAA accumulation (porphyra334, palythine and asterina-330) under blue light also occurred in Neopyropia leucosticta (previously Porphyra leucosticta), whereas white, yellow, green, and red lights favored an increase in shinorine content [57]. In C. crispus, UV-B radiation induced the synthesis of asterina-330, palythinol, and palythene, whereas UV-A radiation induced the synthesis of shinorine and palythine [71]. MAA palythinol content increased under a high level of PAR in Gracilariopsis tenuifrons [72]. MAAs were stimulated in Agarophyton tenuistipitatum (ex-Gracilaria tenuistipitata) by UV radiation, including UV-A and UV-B [73]. The gametophytes of $M$. laminarioides showed a reduction in asterina- 330 and palythine in different radiation treatments, including PAR, PAR + UV-A, and PAR + UV-A + UV-B, whereas tetrasporophytes showed an increase in these MAAs, mainly under PAR + UV-A [59].

Availability of nutrients, particularly inorganic $\mathrm{N}$, is another important factor that positively affects MAA biosynthesis. The $\mathrm{N}$ can be quickly mobilized to MAAs, which act as $\mathrm{N}$ reservoirs [74]. Navarro et al. [75] verified the effects of nitrate $\left(\mathrm{NO}_{3}{ }^{-}\right)$on M. laminarioides grown under solar radiation. The authors observed an increase in mycosporine-glycine that occurred according to the increase in nitrate concentration, reaching saturation at $0.18 \mathrm{mM}$. The interaction between UVR and nutrients was investigated in Gracilariopsis longissima. The experiment showed a $65 \%$ increase in the MAA content under PAR + UV-A + UV-B and high $\mathrm{N}$ availability $\left(300 \mu \mathrm{M} \mathrm{NH}{ }_{4} \mathrm{Cl}\right.$ and $\left.30 \mu \mathrm{M} \mathrm{HNa}_{2} \mathrm{PO}_{4}\right)$ compared to the other treatments with low nutrients $\left(10 \mu \mathrm{M} \mathrm{NH}{ }_{4} \mathrm{Cl}\right.$ and $\left.1 \mu \mathrm{M} \mathrm{HNa}_{2} \mathrm{PO}_{4}\right)$ and without UVR radiation [76]. The MAAs amount also increased 50\% in Gracilaria cornea (previously, Hydropuntia cornea), $40 \%$ in G. longissima, and 30\% in Halopithys incurva when grown under high nutrient concentration $\left(150 \mu \mathrm{M}\right.$ of ammonium $\mathrm{NH}_{4}{ }^{+}$and $15 \mu \mathrm{M}$ of phosphate $\left.\mathrm{PO}_{4}{ }^{3-}\right)$ and PAR + UVA + UV-B radiation, compared with PAR only [54]. A. tenuistipitatum showed an increase in 
MAAs, reaching constant maximum values at concentrations greater than $0.5 \mathrm{mM}$ nitrate $\left(\mathrm{NO}_{3}{ }^{-}\right)$[64]. The same species increased MAAs up to eight-fold in the presence of UVR and $0.5 \mathrm{mM} \mathrm{NO}_{3}{ }^{-}$[63]. N. leucosticta and P. umbilicalis increased MAA content when grown under $300 \mu \mathrm{M}$ ammonium and PAR + UV-A + UV-B radiation [58]. P. columbina also increased the concentration of MAAs under $300 \mu \mathrm{M}$ ammonium, although the increase was greater in PAR + UV-A than in PAR + UV-A + UV-B [77]. P. columbina was also grown under different radiation treatments (PAR and UVR) and different concentrations of nitrate. Samples of this algae were collected during the light and dark (recovery) periods. The highest concentration of MAAs was achieved in samples under PAR + UV-A + UV-B and $0.38 \mathrm{mmol} \mathrm{L}^{-1}$ of $\mathrm{NO}_{3}{ }^{-}$, whereas in the dark the MAAs were higher in PAR and PAR + UV-A + UV-B, without addition of nitrate [53].

\section{Biomass Availability for MAA Production}

The potential application of algae as a source of commercial bioactive compounds requires high biomass availability (Figure 4 ). The global production of macroalgae has tripled during the past 20 years, reaching 32.4 million tons per year. The most cultivated red algae in the world are Eucheuma spp., Gracilaria spp. (for phycocolloid extraction), and Porphyra spp. (for human consumption), cultured mainly in China and Indonesia [78,79]. Algae can be cultured in combination with fish and other aquatic organisms, under integrated multitrophic aquaculture (IMTA) systems, in which the inorganic nutrients (mainly nitrogen and phosphorous) from the fish pond effluents can be used for algae to grow and produce high-value biocompounds.

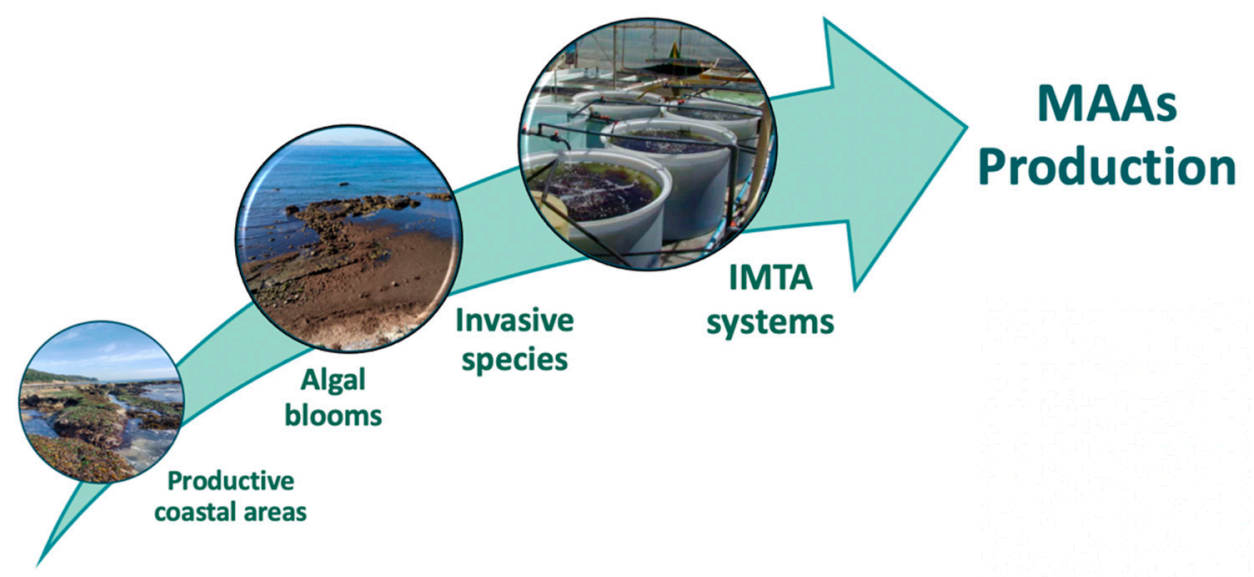

Figure 4. Scheme of the most important source of biomass for MAA production.

High production of MAAs has been reported in algae grown in IMTA using fishpond effluents $[49,65,80,81]$. A. vermiculophyllum and G. cornea were grown under different concentrations of nutrients obtained from fishpond effluents and high concentration of nitrogenous compounds, such as chlorophyll and phycobiliproteins, was observed. The highest yield of MAAs was obtained when G. cornea was grown in fishpond effluents under natural light (sunlight) [81]. Pliego-Cortés et al. [65] cultivated Rhodymenia pseudopalmata under high concentrations of ammonium (around 78.2 to $99.5 \mu \mathrm{M}$ ) using fishpond effluent in IMTA cultivation. The MAA content was five-fold higher compared to wild populations (grown in the natural environment under concentrations around $0.17 \mu \mathrm{M}$ ammonium). Based on the data obtained, the authors presented an estimation of production for $100 \mathrm{~m}^{2}$ of surface, totaling $941 \mathrm{~g}$ DW in $100 \mathrm{~m}^{-2} \mathrm{~d}^{-1}$ of biomass and $1167 \mathrm{mg}$ of MAAs (yield of $1.24 \mathrm{mg}$ MAAs $\mathrm{g}^{-1} \mathrm{DW}$ ). In another study, A. vermiculophyllum was grown for one year in tanks under natural light and addition of fishpond effluents. The MAA content varied seasonally; the highest values were observed in April (about $3.13 \mathrm{mg} \mathrm{g}^{-1} \mathrm{DW}$ ). According to the results of this study, a total amount of $71.33 \mathrm{~g} \mathrm{MAA} \mathrm{year}^{-1}$ could be produced in $100 \mathrm{~m}^{2}[49]$. 
Alternatively, algae biomass can be obtained from very productive coastal areas, e.g., algae from nutrient-enriched areas due to upwellings, as reported in Brazilian or Southern Iberian Peninsula coasts [35,47]. Haroun et al. [82] also reviewed the potential biotechnological use of Macaronesian seaweeds, either wild-collected or cultivated. In this way, algal blooms and invasive species can be a natural source of MAAs. Some authors studied the possible use of these species as source of bioactive compounds, such as A. armata, Sargasum muticum, Caulerpa cylindracea, A. vermiculophyllum, or Grateulopia turuturu [83-87]. The utilization of these species presents two opportunities: (1) high availability of biomass and (2) mitigation of their negative effects, through biomass collection, contributing to ecosystem restoration and sustainability. In relation to red algae, Pinteus et al. [85] reviewed different bioactivities of $A$. armata for possible applications, including MAAs, and Felix et al. [86] analyzed the extraction of UV-absorbing and antioxidant compounds from G. turuturu. Recently, an extensive guide was published on the biotechnological uses of Sargassum spp. accumulated biomass in the Caribbean coast [88].

\section{Extraction Methods}

To date, little information exists about the optimization of MAA extraction in macroalgae at a significant scale. Most authors extracted MAAs by maceration or sonication in distilled water, ethanol, methanol, or different percentages of methanol/ethanol:water and incubation at low temperature. Some authors compared different solvents and obtained a higher extraction with combinations of methanol/ethanol:water, in comparison with only methanol or ethanol extractions $[48,72,77,89,90]$.

Conventional extraction methods included different cell disruption techniques: (1) mechanical (e.g., mortar and pestle or blender type instrument); (2) thermal (e.g., water bath or oven); and (3) chemical (e.g., acid or alkaline solution). The combination of these methods can increase the yield of the extraction. The type of extraction and the solvent used will be selected depending on the physico-chemical characteristics of the molecule of interest and the purpose for its extraction. For cosmeceutical applications, MAA extraction should be undertaken with so-called green solvents, such as water and ethanol, with low or no toxicity [91,92].

In recent years, novel extraction methods have been developed in an attempt to minimize or eliminate the use of non-renewable and polluting solvents in the extraction process of bioactive compounds. As a result, the use of green solvents has increased, leading to higher quality products, decreasing the formation of by-products, improving the separation of products, and avoiding toxicity [93]. Some authors reviewed the different existing novel extraction techniques that can increase the yield and reduce the time of extraction [94-96]; some of these could be used for MAA extraction due to the application of polar and non-toxic solvents:

Enzyme-assisted extraction (EAE): This method is based on the high specificity and selectivity of enzymes in aqueous solutions. Enzymes (such as carrageenases, agarases, or proteases) can degrade the cell wall, releasing the inside bioactive compounds. This technique works under moderate conditions, protecting the molecules of interest from high temperature or acidic/alkaline $\mathrm{pH}$. A disadvantage is the cost of the enzymes, which makes it to scale up the process. EAE has been used in marine organisms to obtain different bioactive compounds, such as polyphenols, fucoidans, carotenoids, and phycobiliproteins [97-102].

Ultrasound-assisted extraction (UAE): This technique uses acoustic waves (20-100 kHz) that travel through the solvent producing cavitation bubbles that can cause cell disruptions. It can be used with a wide variety of solvents, and the temperature during the extraction is relatively low (ice can be used to reduce the temperature). The equipment needed for this extraction is not very expensive, meaning it can be used for large-scale applications. Some studies have indicated that the combination of EAE and UAE generated a synergistic effect, increasing the extraction percentage from $74 \%$ to $91 \%$. UAE has been used by 
different authors to extract polyphenols, polysaccharides, or phycobiliproteins, among others [99,103,104].

Microwave-assisted extraction (MAE): Microwaves (non-ionizing electromagnetic radiation; $300 \mathrm{MHz}-300 \mathrm{GHz}$ ) induce vibration of water molecules inside the cell by interacting with the dipole structure of the water molecule. MAE is a cost-effective technique that can use lower solvent amounts and can be combined with other techniques such as UAE. A disadvantage is that MAE is not suitable for heat-sensitive biocompounds. MAE has been used mainly for polyphenol and fucoidan extraction $[105,106]$.

Pressurized liquid extraction (PLE): This technique is performed at high temperature $\left(50-200{ }^{\circ} \mathrm{C}\right)$ and high pressures (10-15 MPa). The main consequences of PLE utilization are increasing mass transfer, and decreasing the surface tension of solvents and viscosity. This technique allows selective extraction, significantly reducing the extraction times and the amounts of solvents used, with water the most used. PLE has been used by several authors to extract polysaccharides, polyphenols, carotenoids, fucoxanthin, fatty acids, and fucosterol [94,107].

Subcritical Water Extraction (SWE): In this extraction method, water remains in a subcritical state (high pressure and temperature conditions), between the boiling point $\left(100{ }^{\circ} \mathrm{C}\right.$ at 1 bar) and the critical point $\left(374{ }^{\circ} \mathrm{C}\right.$ at 221 bar). It is a simple process, in which the extraction time and the amount of solvent are reduced, and the yield of bioactive substances increases. However, it has an elevated cost for scaling and needs relatively high temperatures. SWE has been used by authors to extract flavanones, fatty acids, carotenoids, phenolic compounds, and sulfated polysaccharides [108-111].

These methods can increase the yield of extraction and reduce time, energy consumption, and waste. The goal of their combination is to determine the optimization of extraction procedures for an industrial application.

\section{Characterization, Identification, and Purification of MAAs}

Chromatography, mainly high performance liquid chromatography (HPLC) with a photodiode array detector (DAD), is the analytical technique commonly used for the analysis and identification of MAAs. The methodology used can vary depending on the polarity of the MAA (e.g., shinorine, porphyra-334, and myc-2-glycine are MAAs with high polarity, whereas asterina-330, palythine, and usurjirine present a low polarity) [25,112-115]. The most recent methodologies try to evaluate a wide variety of MAAs in different species $[72,90,116,117]$. However, HPLC methods are not considered sufficient for safe identification due to the lack of commercial MAA standards. Thus, other procedures such as ESI-MS, NMR, or MALDI-TOF/MS, are required [113,118]. The most recently used methods for identification and characterization of MAAs are summarized in Table 1. 


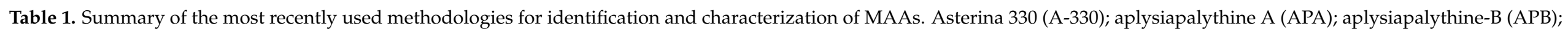

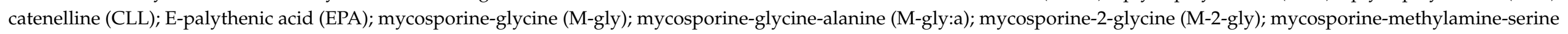

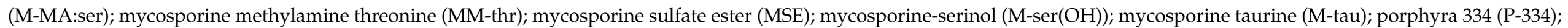

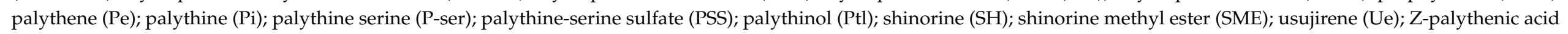

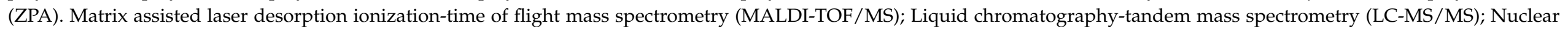

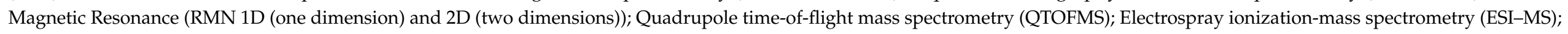

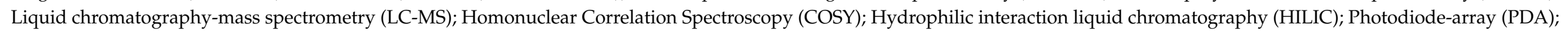
Heteronuclear multiple quantum correlation (HMQC); Hydrogen/Deuterium (H/D).

\begin{tabular}{|c|c|c|c|c|c|c|}
\hline Species & Type of MAAs & Extraction & HPLC Methodology & Purification & Identification & Ref. \\
\hline Palmaria palmata & $\begin{array}{c}\text { SH, Pi, A-330, P-334, Ue, } \\
\text { Pe }\end{array}$ & $\begin{array}{l}\text { Extraction in water }(6 \mathrm{~h} \text {, use } \\
\text { of methanol to remove } \\
\text { impurities) } \\
\text { - Re-dissolve in } 0.1 \% \text { trifluoro } \\
\text { acetic acid (TFA) }\end{array}$ & 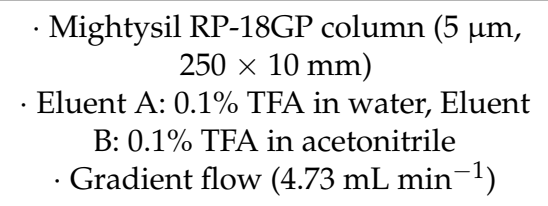 & NO & MALDI-TOF/MS & [119] \\
\hline $\begin{array}{c}\text { Several cyanobacteria: } \\
\text { Microcystis panniformis, } \\
\text { Nostoc sp., Calothix sp. or } \\
\text { Nodularia spunmigena, among } \\
\text { others. }\end{array}$ & SH, P-334, M-glya & $\begin{array}{l}\text { Extraction in } 0.1 \% \text { formic } \\
\text { acid in water }+0.2 \mathrm{mM} \\
\text { ammonium formate }\end{array}$ & $\begin{array}{c}\text {. Luna C18 column }(2)(5 \mu \mathrm{m}, \\
\quad 250 \times 10 \mathrm{~mm}) \\
\text {. Eluent A: } 0.2 \% \text { formic acid in } \\
\text { water + ammonium hydroxide } \\
(\mathrm{pH} 3.15), \text { Eluent B: Milli-Q } \\
\text { water/acetonitrile/methanol } \\
(8: 1: 1)+\text { formic acid }(\mathrm{pH} 2.2), \text { Eluent } \\
\text { C: Acetonitrile/methanol }(1: 1)+0.1 \% \\
\quad \text { formic acid } \\
\text {. Gradient flow }\left(0.5 \mathrm{~mL} \mathrm{~min}{ }^{-1}\right)\end{array}$ & YES & LC-MS/MS & [120] \\
\hline $\begin{array}{c}\text { Agarophyton vermiculophyllum, } \\
\text { Gracilaria cornea, } \\
\text { Graciloriopsis longissima, } \\
\text { Pyropia leucosticta }\end{array}$ & $\begin{array}{c}\text { Pi, A-330, Ptl, SH, P-334, } \\
\text { P-ser }\end{array}$ & $\begin{array}{c}\text { Different extraction and } \\
\text { re-dissolutions methods: } \\
\text { Extraction in water:methanol } \\
\quad(80: 20) \text { and water. } \\
\text { - Redissolution in methanol, } \\
1.5 \% \text { methanol and } 0.15 \% \\
\text { acetic acid in water or water }\end{array}$ & 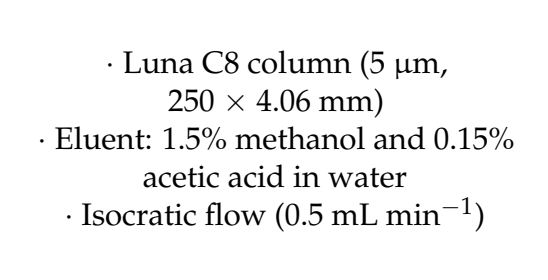 & NO & HPLC-ESI-MS & [121] \\
\hline $\begin{array}{c}\text { Several red algae: } \\
\text { Asparagopsis armata, } \\
\text { Bostrychia scorpioides or } \\
\text { Porphyra dioica, among others }\end{array}$ & $\begin{array}{c}\mathrm{SH}, \mathrm{Pi}, \mathrm{A}-300, \mathrm{P}-334, \mathrm{Ue} \\
\mathrm{Pe}, \text { unknown }\end{array}$ & $\begin{array}{c}\text { - Extraction in water:ethanol } \\
\quad(30: 70)\left(2 \mathrm{~h}, 45^{\circ} \mathrm{C}\right) \\
\cdot \text { Redissolve in } 2.5 \% \text { methanol } \\
\text { and } 0.1 \% \text { acetic acid in water }\end{array}$ & 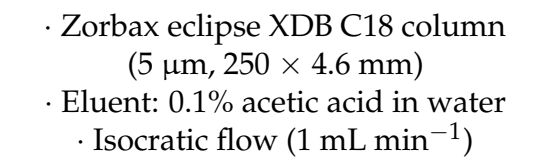 & $\mathrm{NO}$ & LC-ESI-Q-TOF-MS & [45] \\
\hline
\end{tabular}


Table 1. Cont.

\begin{tabular}{|c|c|c|c|c|c|c|}
\hline Species & Type of MAAs & Extraction & HPLC Methodology & Purification & Identification & Ref. \\
\hline $\begin{array}{c}\text { Several red algae: } \\
\text { Pyropia columbina, } \\
\text { Ceramium sp., Pterocladia sp., } \\
\text { or Agarophyton chilense, among } \\
\text { others. }\end{array}$ & $\begin{array}{l}\text { SH, Pi, A-330, P-334, } \\
\text { M-gly, Ue, Pe, APA, APB, } \\
\text { MM-thr, M-gly:a }\end{array}$ & $\begin{array}{l}\text { Extraction with methanol, } \\
\text { followed by three-fold } \\
\text { extractions with } \\
\text { water:methanol } \\
\text { - Redissolve in water }\end{array}$ & 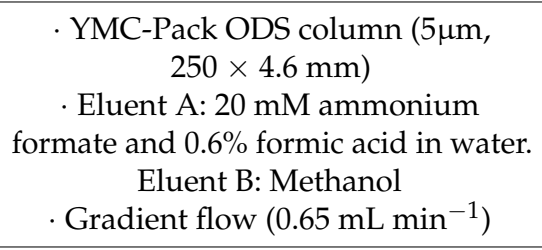 & YES & ESI-MS & {$[122]$} \\
\hline Gracilariopsis tenuifrons & A-330, Ptl, Pe, Ue & $\begin{array}{l}\text { Extraction in water:ethanol } \\
\quad(30: 70)\left(50^{\circ} \mathrm{C}, 1 \mathrm{~h}\right)\end{array}$ & $\begin{array}{c}\text { Z Zorbax C18 column }(250 \times 4.5 \mathrm{~mm}) \\
\cdot \text { Eluent: } 0.1 \text { acetic acid in } \\
\text { water:acetonitrile }(9: 1) \\
\text {. Isocratic flow }\left(0.3 \mathrm{~mL} \mathrm{~min} \mathrm{~min}^{-1}\right)\end{array}$ & $\mathrm{NO}$ & HPLC-ESI-MS & [72] \\
\hline $\begin{array}{l}\text { Cyanobacteria (Calothrix sp. or } \\
\text { Nostoc commune, among } \\
\text { others) and Catenella repens }\end{array}$ & $\begin{array}{c}\text { P-334, SH, M-ser }(\mathrm{OH}) \\
\text { Pi, A-330, CLL }\end{array}$ & $\begin{array}{l}\text { Extraction in water:methanol } \\
\quad(25: 75)\left(45^{\circ} \mathrm{C}, 2 \mathrm{~h}\right)\end{array}$ & 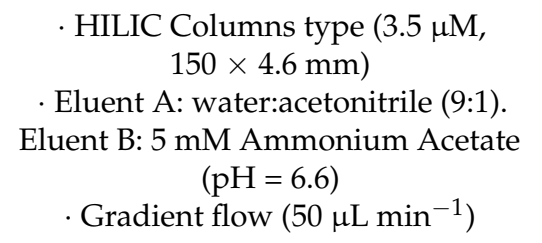 & YES & $\begin{array}{l}\text { HPLC, HILIC, } \\
\text { LC-MS, RMN, } \\
\text { ESI-MS }\end{array}$ & {$[118]$} \\
\hline Porphyra yezoensis & P-334 & $\begin{array}{l}\cdot \text { Extraction with } \\
\text { methanol/water }(80: 20) \\
\qquad\left(45^{\circ} \mathrm{C}, 2 \mathrm{~h}\right)\end{array}$ & $\begin{array}{l}\text { · Gemini-NX } 5 \mu \text { C18 Column } \\
\quad(250 \times 21.2 \mathrm{~mm}) \\
\text {. Eluent: } 0.1 \% \text { acetic acid in water } \\
\text { · Isocratic flow }\left(30 \mathrm{~mL} \mathrm{~min}^{-1}\right)\end{array}$ & YES & ESI-MS & {$[123]$} \\
\hline Gloeocapsa sp. & SH, M-307 & $\begin{array}{l}\text { Extraction with methanol } \\
\qquad\left(4^{\circ} \mathrm{C}, 12 \mathrm{~h}\right)\end{array}$ & 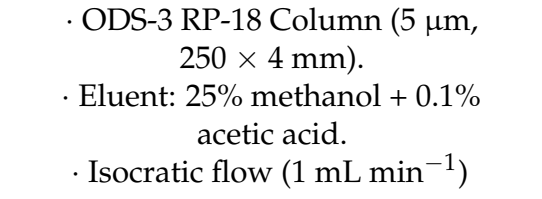 & YES & & {$[124]$} \\
\hline Palmaria palmata & $\begin{array}{c}\mathrm{Pi}, \mathrm{SH}, \mathrm{A}-330, \mathrm{Ptl}, \mathrm{P}-334, \\
\mathrm{Ue}\end{array}$ & $\begin{array}{c}\text { Hydration }+ \text { extraction in } \\
\text { methanol (sonication bath } \\
5 \text { min) }\end{array}$ & $\begin{array}{l}\text { Inertsil ODS-3 column }(5 \mu \mathrm{m}, \\
250 \times 4.6 \mathrm{~mm}) \\
\text { Eluent A: } 0.2 \% \text { formic acid in water. } \\
\text { Eluent B: } 0.2 \% \text { formic acid in } \\
\text { acetonitrile } \\
\text { Gradient flow }\left(1 \mathrm{~mL} \mathrm{~min}{ }^{-1}\right)\end{array}$ & $\mathrm{NO}$ & ESI-MS & {$[125]$} \\
\hline
\end{tabular}


Table 1. Cont.

\begin{tabular}{|c|c|c|c|c|c|c|}
\hline Species & Type of MAAs & Extraction & HPLC Methodology & Purification & Identification & Ref. \\
\hline $\begin{array}{c}\text { Prasiola crispa, } \\
\text { Porphyra umbilicalis }\end{array}$ & Pi, SH, P-334 & $\begin{array}{c}\cdot \text { Extraction with } \\
\text { methanol:water }(25: 75),\left(45^{\circ} \mathrm{C} \text {, }\right. \\
2 \mathrm{~h}) \\
\text { followed by redissolve in } \\
\text { 100\% methanol, } 100 \% \text { water or } \\
\text { (2.5:97.5) Methanol: Water }\end{array}$ & 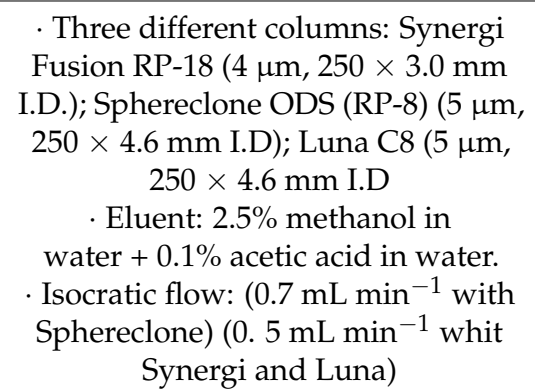 & $\mathrm{NO}$ & & [126] \\
\hline $\begin{array}{c}\text { Neopyropia elongata, } \\
\text { Gelidium corneum, } \\
\text { Ahnfeltiopsis devoniensis and } \\
\text { Lichina pygmaea }\end{array}$ & $\begin{array}{c}\text { P-334, SH, A-330, Pi, } \\
\text { M-gly }\end{array}$ & $\begin{array}{c}\text { Extraction with } \\
\text { methanol:water }(20: 80),\left(45^{\circ} \mathrm{C} \text {, }\right. \\
2 \mathrm{~h}) \text { followed by redissolve in } \\
100 \% \text { methanol. }\end{array}$ & 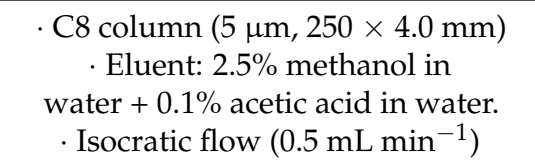 & YES & & [127] \\
\hline Aphanizomeno flos-aquae & P-334 & $\begin{array}{c}\text { Extraction with } \\
\text { methanol/water (80:20) } \\
\text { followed by Chloroform. } \\
\text { Redissolve in } 80 \% \text { Methanol. }\end{array}$ & $\begin{array}{c}\text {. C18 column }(7 \mu \mathrm{m}, 300 \times 7.8 \mathrm{~mm}) \\
\text { Eluent A: }(10: 90) \text { Methanol:Ethanol; } \\
\text { Eluent B: }(90: 10) \text { Methanol: Ethanol. } \\
\text {. Gradient flow }\end{array}$ & YES & $\begin{array}{l}\text { 1D/2D NMR, } \\
\text { Q-TOF-LC-MS, } \\
\text { COSY, HMQC }\end{array}$ & [128] \\
\hline Agarophyton tenuistipitatum & $\mathrm{Pi}, \mathrm{A}-330, \mathrm{Ptl}, \mathrm{SH}$ & $\begin{array}{l}\text { Extraction in water:methanol } \\
(1: 1)(30 \text { min sonication } / 24 \mathrm{~h} \\
\left.\text { at } 4{ }^{\circ} \mathrm{C}\right) \\
\text {. Redissolve in } 0.2 \% \text { acetic acid } \\
\text { in water }\end{array}$ & $\begin{array}{l}\text { · Phenomenex Luna C18 }(5 \mu \mathrm{m} \text {, } \\
\quad 250 \times 10 \mathrm{~mm}) \\
\text { · Eluent: } 0.2 \% \text { acetic acid in water } \\
\text { · Isocratic flow }\left(4.7 \mathrm{~mL} \mathrm{~min}^{-1}\right)\end{array}$ & $\mathrm{NO}$ & $\begin{array}{l}\text { ESI-MS/MS, } \\
\text { ESI-Q-TOF-MS, } \\
\text { HDX-ESI-MS }\end{array}$ & [129] \\
\hline $\begin{array}{c}\text { Different marine organisms } \\
\text { (Red algae: Palmaria decipiens, } \\
\text { Porphyra columbina and } \\
\text { liophylized Porphyra sp. } \\
\text { (Nori)) }\end{array}$ & $\begin{array}{l}\text { PSS, SH, M-2-gly-, MSE, } \\
\text { P-ser, Pi, A-330, P-334, } \\
\text { M-MA:ser, M-gly, Ptl, } \\
\text { ZPA, SME, EPA, MM- } \\
\text { thr, M-tau, Ue, Pe, } \\
\text { M-320, M335/360 }\end{array}$ & $\begin{array}{c}\text { Extraction in water:methanol } \\
(75: 25)\left(2 \mathrm{~h}, 45^{\circ} \mathrm{C}, 3 \text { times }\right) \\
\text { Redissolve in } 0.2 \% \text { TFA and } \\
\text { ammonium hydroxide } \\
\text { (pH 3.15) }\end{array}$ & $\begin{array}{c}\text { Two C18 columns in tandem: Alltima } \\
(5 \mu \mathrm{m}, 150 \times 4.6 \mathrm{~mm}) \text { and CapCell } \\
\text { Pak UG }(5 \mu \mathrm{m}, 250 \times 4.6 \mathrm{~mm}) \\
\text { Eluent A: } 0.2 \% \mathrm{TFA} \text { and ammonium } \\
\text { hydroxide in water }(\mathrm{pH} 3.15) \text {. Eluent } \\
\text { B: eluent A } \\
\text { (pH 2.2):methanol:acetonitrile } \\
\text { (80:10:10) } \\
\text { Gradient flow }\end{array}$ & NO & $\mathrm{LC} / \mathrm{MS}$ & [90] \\
\hline
\end{tabular}


Table 1. Cont.

\begin{tabular}{|c|c|c|c|c|c|c|}
\hline Species & Type of MAAs & Extraction & HPLC Methodology & Purification & Identification & Ref. \\
\hline Pyropia columbina & $\begin{array}{c}\text { M-gly, } \mathrm{SH}, \mathrm{P}-334, \mathrm{Pi}, \\
\text { A-330 }\end{array}$ & $\begin{array}{l}\text { Extraction in water:methanol } \\
(80: 20)\left(2 \mathrm{~h}, 45^{\circ} \mathrm{C}\right) \cdot \text { Redissolve } \\
\text { in methanol }\end{array}$ & 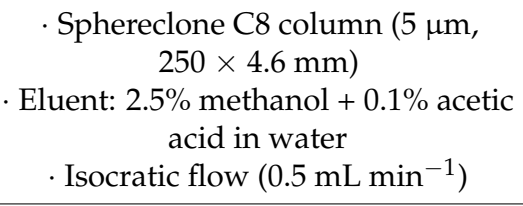 & NO & & [77] \\
\hline Crassyphicus corneus & SH, P-334 & $\begin{array}{c}\text { Extraction in water:methanol } \\
(80: 20)\left(2.5 \mathrm{~h}, 45^{\circ} \mathrm{C}\right) \\
\text { - Redissolve in methanol }\end{array}$ & 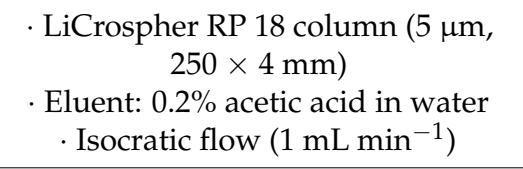 & $\mathrm{NO}$ & & [130] \\
\hline Chondrus crispus & $\mathrm{Pi}, \mathrm{SH}, \mathrm{Ptl}, \mathrm{Pe}$ & $\begin{array}{c}\text { Extraction in water:methanol } \\
(75: 25)\left(2 \mathrm{~h}, 45^{\circ} \mathrm{C}\right) \\
\cdot \text { Redissolve in methanol }\end{array}$ & $\begin{array}{c}\text { Spherisorb RP } 8 \text { column }(5 \mu \mathrm{m} \text {, } \\
250 \times 4 \mathrm{~mm}) \\
\text {. Eluent: } 25 \% \text { met }+0.1 \% \text { acetic acid } \\
\text { in water } \\
\text {. Isocratic flow }\left(0.7 \mathrm{~mL} \mathrm{~min}^{-1}\right)\end{array}$ & NO & & [131] \\
\hline
\end{tabular}


Chromatography is a general analytical technique used to separate a mixture into its individual components. In relation to the MAA purification process, there are different approaches depending on the chemical characteristics and the aim. In the case of its use for cosmeceutical products, the ideal is an extraction and purification free of hazardous solvents for the environment and health, which increases the biocompatibility and safety of the final product. However, to date, very few methodologies use green solvents for the identification and purification of MAAs. This indicates an opportunity to explore new methodologies and techniques for the identification and purification of these molecules with green solvents [121,132-134]. It is important to note that there are different criteria and legislations for the selection of green solvents, for which some solvents, such as alcohols of methanol or propanol type, are allowed in low amounts depending on the legislation (e.g., European Chemicals Agency, ECHA).

In recent decades, different authors have attempted to purify MAAs. The different strategies vary from simple columns of a resin that are not automated to highly complex systems as UHPLC coupled to a fraction-collection device or liquid-liquid chromatography. Torres et al. [128] purified the MAA porphyra-334 using a silica gel column. A methanolic extraction was chromatographed on a silica gel column using a gradient of ethanol and methanol as eluent. De la Coba et al. [127] isolated porphyra-334, shinorine, asterine-330, and palythine using adsorption and ionic exchange chromatography. First, the MAA extractions were blended with activated charcoal (adsorption) and eluted with methanol:water (1:1). The fraction obtained was dried, re-dissolved in distilled water, and passed through a Dowex $50 \mathrm{~W}-\mathrm{X} 8$ ( $\mathrm{H}^{+}$form; 50-100 um mesh) ion exchange column. To separate porphyra-334 and shinorine, distilled water was used as eluent, whereas to separate asterina-330 and palythine, the authors used a gradient of distilled water and $0.35 \mathrm{M}$ $\mathrm{HCl}$. Roullier et al. [135] isolated mycosporine-serinol using centrifugal partition chromatography (CPC). A system composed of n-butanol, acetic acid, and water (4:1:5, v/v/v) was used. Ryu et al. [123] also purified the MAA porphyra-344. An aqueous-methanolic extract (water:methanol; 4:1) was dried, redissolved in ultrapure water, and transferred to a separating funnel containing chloroform-methanol-ultrapure water. The water fraction, called the crude MAA fraction, was identified through LC/MS. Hartmann et al. [118] also used a Dowex column (50 WX $\mathrm{H}^{+}$form, 100-200 um mesh) to obtain a MAA-enriched fraction, as a pre-purification step. The purification was realized by semi-preparative HPLC with a Lichrosorb C18 $100 \AA$ column $(7 \mathrm{um}, 200 \times 10 \mathrm{~mm})$ and a mobile phase containing $0.1 \%$ acid acetic in water (A) and acetonitrile (B). Boulhbo et al. [136] also used CPC for fractioning of UV-B absorbing molecules. More recently, Orfanoudaki et al. [122] described the purification of 11 MAAs, using a combination of silica gel column chromatography, flash chromatography, semi-preparative HPLC on diverse stationary phases, and fast centrifugal partition chromatography (FCPC). Geraldes et al. [124] purified porphyra-334, shinorine and mycoposrine-glycine-alanine using a semi-preparative HPLC with a Luna C18 column $(5 \mu \mathrm{m}, 250 \times 10 \mathrm{~mm})$ and a fraction collector. As mobile phase the authors used a gradient of: (A) $0.2 \%(v / v)$ formic acid solution + ammonium hydroxide ( $\mathrm{pH} 3.15)$; (B) Milli-Q water/acetonitrile/methanol (8:1:1) + formic acid ( $\mathrm{pH} 2.20)$; and (C) acetonitrile/methanol $(1: 1)+0.1 \%(v / v)$ formic acid (phase $\mathrm{C})$. The MAAs were quantified and the method validated by LC-MS/MS.

Semi-preparative and preparative HPLC are the methods associated with scaling up the purification of small molecules. With bigger columns and a higher flow than analytic HPLC, it is possible to obtain a higher amount of these molecules with a high degree of purity. However, the cost of the equipment still limits its widespread use [137]. Alternatively, liquid-liquid chromatography (such CPC) is a very attractive method used for separation of different natural molecules, due to its capacity to be scaled up. This technique presents various advantages in comparison with HPLC, including: (1) no use of columns with solid phase; (2) high loading capacity; (3) total recovery of the injected sample; (4) low risk of sample denaturalization; (5) low solvent consumption [138,139]. 


\section{MAA Bioactivities}

Considering the ability of MAAs to absorb light between 310 and $360 \mathrm{~nm}$, which comprises the UV-B and UV-A spectrum, numerous studies have focused on their potential for the development of natural sunscreens. UV radiation also induces high production of reactive oxygen species (ROS) that can promote other effects, such as premature skin aging or immunosuppression. Thus, photoprotection also involves other bioactivities such as antioxidant, immuno-modulatory, or anti-aging properties [41,140,141] (Figure 5).

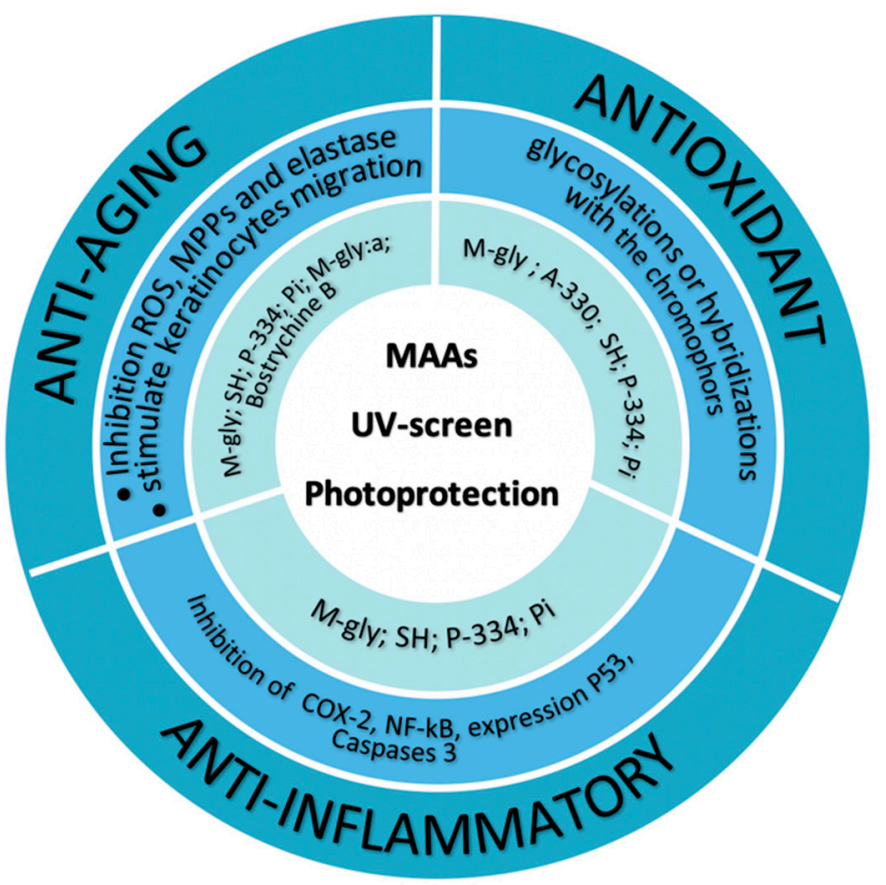

Figure 5. Scheme of the different bioactivities described in MAAs, indicating the relevance of some MAAs [33,41,47,123,127,142-155].

Several authors analyzed the potential antioxidant activity of MAAs in vitro. Wada et al. [41] reviewed the molecular diversity of MAAs and their antioxidant activities. De la Coba et al. [127] evaluated, using different methods, the antioxidant potential of different MAAs (mycglycine, asterine-330, shinorine, and porphyra-334). The authors found that the antioxidant activity of all MAAs depended on the dose and $\mathrm{pH}$, with greater activity in alkaline $\mathrm{pH}$. Mycosporine-glycine showed the highest activity in all $\mathrm{pH}$ tested. This MAA had previously shown concentration-dependent antioxidant potential [142]. More recently, Torres et al. [143] observed high antioxidant activity in some imino-MAAs (palythine, asterina-330, shinorine, or porphyra-334) under alkaline $\mathrm{pH}$. However, they also found pro-oxidant effects in some of these MAAs. Most of the studies concluded that MAAs can eliminate ROS in vitro, although the role of these molecules in vivo is not yet fully understood. In addition, the antioxidant activity of MAAs can also increase due to changes in the molecules such as glycosylations or hybridizations with the chromophors [41].

A high production of ROS can also cause elastic fiber dystrophy and secretion of elastases, which activate matrix metalloproteinases (MMPs). MMPs and elastases degrade collagen and elastin fibers, respectively. The reduction of collagen and elastin leads to the formation of wrinkles and accelerated aging [144]. For this reason, MAAs that prevent ROS production and activation of MMPs have high potential to prevent photoaging. Ryu et al. [123] studied the anti-photoaging role of the MAA porphyra-334. This MAA reduces the reactive oxygen species (ROS) production and the levels of matrix metalloproteinases (MMPs) in human fibroblasts exposed to UV-A. Hartmann et al. [145] also demonstrated the inhibition of metalloproteinases by porphyra-334, shinorine, and paly- 
thine. Orfanoudaki et al. [146] investigated the collagenase inhibition activity of different isolated MAAs. The authors proved the collagenase inhibition activity for all MAAs, and the inhibition of glycation end products in most of MAAs, which is a property that prevents a decrease in skin elasticity. They also evidenced the ability of shinorine, porphyra-334, mycosporine-glycine-alanine, and bostrychine B to stimulate human keratinocyte migration in vitro, indicating a wound-healing property.

Oxidative stress can also activate various biochemical pathways related to immunemodulatory activities. In UV-induced inflammation, cyclooxygenase-2 (COX-2) mRNA is overexpressed. Some MAAs have the potential to suppress this gene, such as mycosporineglycine [147]. According to Lawrence et al. [33], the expression of COX-2 appears to be linked to shorter UV wavelengths. Thus, MAAs that absorb shorter wavelengths, such as mycosporine-glycine and shinorine, would be more effective in inhibiting COX-2. Exposure to UV radiation can also activate the nuclear transcription factor- $\kappa \mathrm{B}(\mathrm{NF}-\kappa \mathrm{B})$, which regulates the expression of pro-inflammatory molecules. Tryptophan metabolism is also involved in immunoregulation, and its breakdown and availability depend on an IDO-1 enzyme. NF- $\mathrm{BB}$ and IDO-1 appear to be affected by antioxidant molecules. Becker et al. [148] evaluated the influence of shinorine and porphyra-334 on NF- $\mathrm{kB}$ activation and tryptophan metabolism. In spite of the similar structure of both MAAs, diverse effects were observed, i.e., both MAAs were able to induce NF- $\kappa$ B activity in unstimulated THP-1-Blue cells, whereby the increase was dose-dependent and more pronounced with shinorine treatment. Although shinorine also slightly superinduced NF- $\mathrm{B}$ in LPS-stimulated cells, porphyra-334 reduced NF-kB activity in this inflammatory background.

Different authors analyzed the capacity of algae extracts and creams that contain algae extracts to absorb UV radiation, measuring the in vitro sun protection factor (SPF). De la Coba et al. [149] formulated three different galenic formulations that contain around $5 \%$ of different MAAs and measured the SPF, obtaining values that varied from 4.5 to 8.3, depending on the type of MAAs. Because erythema is not the only effect of the UV radiation on the skin, the authors proposed the calculation of protection factors against other biological effects (such immunosuppression, photoaging, or DNA damage), named biological effective protection factors (BEPFs). Other authors studied the SPF of concentrated algae extracts. Gracilariopsis longissima extract with a MAA content of $1.6 \mathrm{mg} \mathrm{g}^{-1}$ DW, showed SPF values between 2 and 7.5, depending on the biomass concentration [150], whereas Porphyra umbilicalis extract with a much higher MAA content $\left(10 \mathrm{mg} \mathrm{g}^{-1} \mathrm{DW}\right)$ reached an SPF value of 18 in the highest concentration [47]. These authors also proposed another index to measure photoprotection, the effective solar absorpted radiation (ESAR), that measures the percentage of effective solar radiation against any biological effect that can be absorbed by a cream. However, the values obtained from extracts are not applicable in practice due to the dilution needed to be incorporated in the lotions.

The photoprotective capacity has also been demonstrated in vivo, on mouse skin. Studies demonstrated that MAAs can prevent UV-induced skin damage, inhibiting the expression of p53 and caspase- 3 (protein indicators of apoptosis), increasing the antioxidant enzymes activities, and inhibiting inflammation [151-153]. Lawrence et al. [154] observed that the MAA palythine (even at low concentration) also reduces the damage caused by UV radiation in human keratinocytes. Rui et al. [155] also observed that MAAs can reduce photoaging induced by UV radiation in mouse skin, by interfering with collagen metabolism. Treatment with MAAs inhibited collagen degradation by the MMPs and promoted collagen synthesis.

\section{Commercial Applications}

As previously mentioned, numerous studies suggest the use of MAAs as UV screen substances $[23,33,41,146]$. However, at present, few products based on MAAs and/or red algae extracts are commercially available.

Helioguard ${ }^{\mathrm{TM}_{3}} 35$ is a natural UV-screening active principle based on MAAs from Porphyra umbilicalis, commercialized by the Mibelle group. This product has been demon- 
strated to exhibit photoprotective properties against UV-A radiation and presents other beneficial effects for the skin, such as inhibition of lipid peroxidation, and improvement of the firmness and smoothness. Helionori ${ }^{\circledR}$ is another active ingredient based on a MAAenriched extract from Porphyra umbilicalis commercialized by the Gelyma company. It can act as a natural UV-A photoprotector, prevents the formation of sunburn cells, protects cell metabolism against UVA irradiation, and protects DNA and cell membranes against UV-A. Ronacare ${ }^{\circledR}$ RenouMer is also a commercial active principle based on Polysipohonia elongate extracts, which can reduce skin roughness, present anti-wrinkle effects, and improve skin hydration.

The sunscreen commercialized with the name ALGA MARIS ${ }^{\circledR}$ (Laboratoires Biarritz, Biarritz, France) contains Gelidium corneum extracts (Alga-Gorria ${ }^{\circledR}$ ) enriched in oligoelements and antioxidants such as flavonoids or carotenoids. This sunscreen is a combination of physical filters that protect against UV-B and UV-A radiation, and Alga-Gorria ${ }^{\circledR}$, an algal extract that neutralizes the free radicals and protects against premature skin aging.

\section{Conclusions and Future Perspectives}

In the near future, the use of MAAs in cosmeceutical products is expected to increase due to their excellent properties as natural UV photoprotectors, such as high photo- and thermo-stability, and the lack of oxidant photoproducts after UV absorption. MAAs also present other interesting bioactivities for the skin, such as antioxidant and antiinflammatory properties, protection of collagen and elastin by the inhibition of collagenase and elastase, and DNA protection by reducing dimer production. The significant diversity of cosmeceutical properties of MAAs has attracted the attention of the scientific community and companies, as observed in the large number of reviews and book chapters published in recent years $[1,23,33,41,69,140,156,157]$.

The limitation of available biomass to extract MAAs can be addressed by culturing macroalgae in $\mathrm{N}$-enriched waters originating from fishpond effluents (IMTA systems) or using invasive species that contain MAAs. In addition, the application of photobiological treatments in algal culture, such as UV-Blue radiation treatments, can substantially increase the MAA content. Finally, it is expected that new advances in extraction and purification techniques will reduce the cost of production of MAAs for use in cosmeceutical products (Figure 1).

Author Contributions: All authors contributed substantially to this review. Conceptualization: J.V. and F.L.F., Investigation: J.V., G.S., B.R.M., C.H., J.B.-B., F.L.F., Writing-original draft: J.V., G.S., B.R.M., C.H., J.B.-B., F.L.F., Writing-review and editing: J.V., G.S., B.R.M., C.H., J.B.-B., F.L.F. All authors have read and agreed to the published version of the manuscript.

Funding: This research was funded by the Project UMA18-FEDER JA162 (Junta de Andalucía).

Acknowledgments: J.V. thanks the MedArtSal project (ENI CBC Med) for her technical contract. G.S., B.R.M., C.H. and J.B.-B. thanks the support of the Coordenação de Aperfeiçoamento de Pessoal de Nível Superior-Brasil (CAPES)—Finance Code 001(proc. n. 88882.438333/2019-01, 88887.578926/2020-00, 88882.438349/2019-01, 88887.374403/2019-00). J.B.-B. also acknowledge the National Council for Scientific and Technological Development (CNPq, proc. n. 432572/2018-0 and 304122/2017-3). J.V. and F.L.F. are also grateful to the Junta de Andalucia for the support of their research group "Photobiology and Biotechnology of Aquatic Organism" (FYBOA, RNM-295).

Conflicts of Interest: The authors declare no conflict of interest.

\section{References}

1. Kim, S.K.; Chojnacka, K. Marine Algae Extracts: Processes, Products, and Applications; Wiley: Hoboken, NJ, USA, 2015; Volume 1-2, ISBN 9783527679577.

2. Navarro, N.; Figueroa, F.L.; Korbee, N.; Bonomi, J.; Álvarez Gómez, F.; de la Coba, F. Mycosporine-like amino acids from red algae to develop natural UV sunscreens. In Sunscreens: Source, Formulations, Efficacy and Recommendations; Rastogi, R.P., Ed.; NOVA Science Publisher: Hauppauge, NY, USA, 2018; pp. 99-129, ISBN 9781536132953.

3. Leandro, A.; Pereira, L.; Gonçalves, A.M.M. Diverse Applications of Marine Macroalgae. Mar. Drugs 2019, 18, 17. [CrossRef] 
4. Ichihashi, M.; Ueda, M.; Budiyanto, A.; Bito, T.; Oka, M.; Fukunaga, M.; Tsuru, K.; Horikawa, T. UV-induced skin damage. Toxicology 2003, 189, 21-39. [CrossRef]

5. Matsumura, Y.; Ananthaswamy, H.N. Toxic effects of ultraviolet radiation on the skin. Toxicol. Appl. Pharmacol. 2004, 195, 298-308. [CrossRef]

6. Wölfle, U.; Seelinger, G.; Bauer, G.; Meinke, M.C.; Lademann, J.; Schempp, C.M. Reactive Molecule Species and Antioxidative Mechanisms in Normal Skin and Skin Aging. Skin Pharmacol. Physiol. 2014, 27, 316-332. [CrossRef] [PubMed]

7. Tsui, M.M.P.; Leung, H.W.; Wai, T.C.; Yamashita, N.; Taniyasu, S.; Liu, W.; Lam, P.K.S.; Murphy, M.B. Occurrence, distribution and ecological risk assessment of multiple classes of UV filters in surface waters from different countries. Water Res. 2014, 67, 55-65. [CrossRef] [PubMed]

8. Sánchez Rodríguez, A.; Rodrigo Sanz, M.; Betancort Rodríguez, J.R. Occurrence of eight UV filters in beaches of Gran Canaria (Canary Islands): An approach to environmental risk assessment. Chemosphere 2015, 131, 85-90. [CrossRef]

9. Sánchez-Quiles, D.; Tovar-Sánchez, A. Are sunscreens a new environmental risk associated with coastal tourism? Environ. Int. 2015, 83, 158-170. [CrossRef] [PubMed]

10. Gago-Ferrero, P.; Alonso, M.B.; Bertozzi, C.P.; Marigo, J.; Barbosa, L.; Cremer, M.; Secchi, E.R.; Azevedo, A.; Lailson-Brito, J.; Torres, J.P.M.; et al. First determination of UV filters in marine mammals. Octocrylene levels in Franciscana dolphins. Environ. Sci. Technol. 2013, 47, 5619-5625. [CrossRef]

11. Picot Groz, M.; Martinez Bueno, M.J.; Rosain, D.; Fenet, H.; Casellas, C.; Pereira, C.; Maria, V.; Bebianno, M.J.; Gomez, E. Detection of emerging contaminants (UV filters, UV stabilizers and musks) in marine mussels from Portuguese coast by QuEChERS extraction and GC-MS/MS. Sci. Total Environ. 2014, 493, 162-169. [CrossRef] [PubMed]

12. Miller, R.J.; Lenihan, H.S.; Muller, E.B.; Tseng, N.; Hanna, S.K.; Keller, A.A. Impacts of metal oxide nanoparticles on marine phytoplankton. Environ. Sci. Technol. 2010, 44, 7329-7334. [CrossRef] [PubMed]

13. Weisbrod, C.J.; Kunz, P.Y.; Zenker, A.K.; Fent, K. Effects of the UV filter benzophenone-2 on reproduction in fish. Toxicol. Appl. Pharmacol. 2007, 225, 255-266. [CrossRef]

14. Blüthgen, N.; Zucchi, S.; Fent, K. Effects of the UV filter benzophenone-3 (oxybenzone) at low concentrations in zebrafish (Danio rerio). Toxicol. Appl. Pharmacol. 2012, 263, 184-194. [CrossRef]

15. Downs, C.A.; Kramarsky-Winter, E.; Segal, R.; Fauth, J.; Knutson, S.; Bronstein, O.; Ciner, F.R.; Jeger, R.; Lichtenfeld, Y.; Woodley, C.M.; et al. Toxicopathological Effects of the Sunscreen UV Filter, Oxybenzone (Benzophenone-3), on Coral Planulae and Cultured Primary Cells and Its Environmental Contamination in Hawaii and the U.S. Virgin Islands. Arch. Environ. Contam. Toxicol. 2016, 70, 265-288. [CrossRef] [PubMed]

16. Tsui, M.M.P.; Lam, J.C.W.; Ng, T.Y.; Ang, P.O.; Murphy, M.B.; Lam, P.K.S. Occurrence, Distribution, and Fate of Organic UV Filters in Coral Communities. Environ. Sci. Technol. 2017, 51, 4182-4190. [CrossRef]

17. Moeller, M.; Pawlowski, S.; Petersen-Thiery, M.; Miller, I.B.; Nietzer, S.; Heisel-Sure, Y.; Kellermann, M.Y.; Schupp, P.J. Challenges in Current Coral Reef Protection-Possible Impacts of UV Filters Used in Sunscreens, a Critical Review. Front. Mar. Sci. 2021, 8 , 383. [CrossRef]

18. Avenel-Audran, M.; Dutartre, H.; Goossens, A.; Jeanmougin, M.; Comte, C.; Bernier, C.; Benkalfate, L.; Michel, M.; FerrierLebouëdec, M.C.; Vigan, M.; et al. Octocrylene, an emerging photoallergen. Arch. Dermatol. 2010, 146, 753-757. [CrossRef] [PubMed]

19. Krause, M.; Klit, A.; Blomberg Jensen, M.; Søeborg, T.; Frederiksen, H.; Schlumpf, M.; Lichtensteiger, W.; Skakkebaek, N.E.; Drzewiecki, K.T. Sunscreens: Are they beneficial for health? An overview of endocrine disrupting properties of UV-filters. Int. J. Androl. 2012, 35, 424-436. [CrossRef]

20. Sinha, R.P.; Singh, S.P.; Häder, D.P. Database on mycosporines and mycosporine-like amino acids (MAAs) in fungi, cyanobacteria, macroalgae, phytoplankton and animals. J. Photochem. Photobiol. B Biol. 2007, 89, 29-35. [CrossRef] [PubMed]

21. Sun, Y.; Zhang, N.; Zhou, J.; Dong, S.; Zhang, X.; Guo, L.; Guo, G. Distribution, contents, and types of mycosporine-like amino acids (MAAs) in marine macroalgae and a database for Maas based on these characteristics. Mar. Drugs 2020, 18, 43. [CrossRef] [PubMed]

22. Carreto, J.I.; Carignan, M.O. Mycosporine-Like Amino Acids: Relevant Secondary Metabolites. Chemical and Ecological Aspects. Mar. Drugs 2011, 9, 387-446. [CrossRef] [PubMed]

23. Chrapusta, E.; Kaminski, A.; Duchnik, K.; Bober, B.; Adamski, M.; Bialczyk, J. Mycosporine-Like Amino Acids: Potential Health and Beauty Ingredients. Mar. Drugs 2017, 15, 326. [CrossRef] [PubMed]

24. Favre-Bonvin, J.; Bernillon, J.; Salin, N.; Arpin, N. Biosynthesis of mycosporines: Mycosporine glutaminol in Trichothecium roseum. Phytochemistry 1987, 26, 2509-2514. [CrossRef]

25. Shick, J.M.; Romaine-Lioud, S.; Romaine-Lioud, S.; Ferrier-Pagès, C.; Gattuso, J.-P. Ultraviolet-B radiation stimulates shikimate pathway-dependent accumulation of mycosporine-like amino acids in the coral Stylophora pistillata despite decreases in its population of symbiotic dinoflagellates. Limnol. Oceanogr. 1999, 44, 1667-1682. [CrossRef]

26. Sinha, R.P.; Ambasht, N.K.; Sinha, J.P.; Häder, D.P. Wavelength-dependent induction of a mycosporine-like amino acid in a rice-field cyanobacterium, Nostoc commune: Role of inhibitors and salt stress. Photochem. Photobiol. Sci. 2003, 2, 171-176. [CrossRef] [PubMed]

27. Balskus, E.P.; Walsh, C.T. The genetic and molecular basis for sunscreen biosynthesis in cyanobacteria. Science 2010, 329, 1653-1656. [CrossRef] [PubMed] 
28. Singh, S.P.; Klisch, M.; Sinha, R.P.; Häder, D.P. Genome mining of mycosporine-like amino acid (MAA) synthesizing and non-synthesizing cyanobacteria: A bioinformatics study. Genomics 2010, 95, 120-128. [CrossRef] [PubMed]

29. Rosic, N.N. Phylogenetic analysis of genes involved in mycosporine-like amino acid biosynthesis in symbiotic dinoflagellates. Appl. Microbiol. Biotechnol. 2012, 94, 29-37. [CrossRef]

30. Gao, Q.; Garcia-Pichel, F. An ATP-Grasp ligase involved in the last biosynthetic step of the iminomycosporine shinorine in nostoc punctiforme ATCC 29133. J. Bacteriol. 2011, 193, 5923-5928. [CrossRef] [PubMed]

31. Spence, E.; Dunlap, W.C.; Shick, J.M.; Long, P.F. Redundant Pathways of Sunscreen Biosynthesis in a Cyanobacterium. ChemBioChem 2012, 13, 531-533. [CrossRef] [PubMed]

32. Pope, M.A.; Spence, E.; Seralvo, V.; Gacesa, R.; Heidelberger, S.; Weston, A.J.; Dunlap, W.C.; Shick, J.M.; Long, P.F. Omethyltransferase is shared between the pentose phosphate and shikimate pathways and is essential for mycosporine-like amino acid biosynthesis in Anabaena variabilis ATCC 29413. ChemBioChem 2015, 16, 320-327. [CrossRef]

33. Lawrence, K.P.; Long, P.F.; Young, A.R. Mycosporine-Like Amino Acids for Skin Photoprotection. Curr. Med. Chem. 2017, 25, 5512-5527. [CrossRef] [PubMed]

34. PubChem Identifier: CID 14444486. Available online: https: / / pubchem.ncbi.nlm.nih.gov / compound/14444486\#section=2DStructure (accessed on 20 May 2021).

35. PubChem Identifier: CID 16047608. Available online: https: / / pubchem.ncbi.nlm.nih.gov / compound/16047608\#section=2DStructure (accessed on 20 May 2021).

36. PubChem Identifier: CID 13194807. Available online: https:// pubchem.ncbi.nlm.nih.gov / compound/13194807\#section=2DStructure (accessed on 20 May 2021).

37. PubChem Identifier: CID 9948334. Available online: https://pubchem.ncbi.nlm.nih.gov/compound/9948334\#section=2DStructure (accessed on 20 May 2021).

38. PubChem Identifier: CID 10471931. Available online: https:// pubchem.ncbi.nlm.nih.gov / compound/10471931\#section=2DStructure (accessed on 20 May 2021).

39. PubChem Identifier: CID 91864535. Available online: https://pubchem.ncbi.nlm.nih.gov/ compound/91864535\#section=2DStructure (accessed on 20 May 2021).

40. PubChem Identifier: CID 21773785. Available online: https: / / pubchem.ncbi.nlm.nih.gov / compound/21773785\#section=2DStructure (accessed on 20 May 2021).

41. Wada, N.; Sakamoto, T.; Matsugo, S. Mycosporine-Like Amino Acids and Their Derivatives as Natural Antioxidants. Antioxidants 2015, 4, 603-646. [CrossRef]

42. Huovinen, P.; Gómez, I.; Figueroa, F.L.; Ulloa, N.; Morales, V.; Lovengreen, C. Ultraviolet-absorbing mycosporine-like amino acids in red macroalgae from Chile. Bot. Mar. 2004, 47, 21-29. [CrossRef]

43. Briani, B.; Sissini, M.N.; Lucena, L.A.; Batista, M.B.; Costa, I.O.; Nunes, J.M.C.; Schmitz, C.; Ramlov, F.; Maraschin, M.; Korbee, N.; et al. The influence of environmental features in the content of mycosporine-like amino acids in red marine algae along the Brazilian coast. J. Phycol. 2018, 54, 380-390. [CrossRef]

44. Karsten, U.; Sawall, T.; West, J.; Wiencke, C. Ultraviolet sunscreen compounds in epiphytic red algae from mangroves. Hydrobiologia 2000, 432, 159-171. [CrossRef]

45. Lalegerie, F.; Lajili, S.; Bedoux, G.; Taupin, L.; Stiger-Pouvreau, V.; Connan, S. Photo-protective compounds in red macroalgae from Brittany: Considerable diversity in mycosporine-like amino acids (MAAs). Mar. Environ. Res. 2019, 147, 37-48. [CrossRef] [PubMed]

46. Alvarez-Gomez, F.; Korbee, N.; Figueroa, F.L. Analysis of antioxidant capacity and bioactive compounds in marine macroalgal and lichenic extracts using different solvents and evaluation methods. Cienc. Mar. 2016, 42, 271-288. [CrossRef]

47. Schneider, G.; Figueroa, F.L.; Vega, J.; Chaves, P.; Álvarez-Gómez, F.; Korbee, N.; Bonomi-Barufi, J. Photoprotection properties of marine photosynthetic organisms grown in high ultraviolet exposure areas: Cosmeceutical applications. Algal Res. 2020, 49, 101956. [CrossRef]

48. Vega, J.; Bonomi-Barufi, J.; Gómez-Pinchetti, J.L.; Figueroa, F.L. Cyanobacteria and Red Macroalgae as Potential Sources of Antioxidants and UV Radiation-Absorbing Compounds for Cosmeceutical Applications. Mar. Drugs 2020, 18, 659. [CrossRef]

49. Barceló-Villalobos, M.; Figueroa, F.L.; Korbee, N.; Álvarez-Gómez, F.; Abreu, M.H. Production of Mycosporine-Like Amino Acids from Gracilaria vermiculophylla (Rhodophyta) Cultured Through One Year in an Integrated Multi-trophic Aquaculture (IMTA) System. Mar. Biotechnol. 2017, 19, 246-254. [CrossRef]

50. Guihéneuf, F.; Gietl, A.; Stengel, D.B. Temporal and spatial variability of mycosporine-like amino acids and pigments in three edible red seaweeds from western Ireland. J. Appl. Phycol. 2018, 30, 2573-2586. [CrossRef]

51. Lalegerie, F.; Stiger-Pouvreau, V.; Connan, S. Temporal variation in pigment and mycosporine-like amino acid composition of the red macroalga Palmaria palmata from Brittany (France): Hypothesis on the MAA biosynthesis pathway under high irradiance. $J$. Appl. Phycol. 2020, 32, 2641-2656. [CrossRef]

52. Figueroa, F.L.; Escassi, L.; Pérez-Rodríguez, E.; Korbee, N.; Giles, A.D.; Johnsen, G. Effects of short-term irradiation on photoinhibition and accumulation of mycosporine-like amino acids in sun and shade species of the red algal genus Porphyra. J. Photochem. Photobiol. B Biol. 2003, 69, 21-30. [CrossRef] 
53. Navarro, N.P.; Mansilla, A.; Figueroa, F.L.; Korbee, N.; Jofre, J.; Plastino, E. Short-term effects of solar UV radiation and NO ${ }_{3}{ }^{-}$ supply on the accumulation of mycosporine-like amino acids in Pyropia columbina (Bangiales, Rhodophyta) under spring ozone depletion in the sub-Antarctic region, Chile. Bot. Mar. 2014, 57, 9-20. [CrossRef]

54. Álvarez-Gómez, F.; Korbee, N.; Figueroa, F.L. Effects of UV Radiation on Photosynthesis, Antioxidant Capacity and the Accumulation of Bioactive Compounds in Gracilariopsis longissima, Hydropuntia cornea and Halopithys incurva (Rhodophyta). J. Phycol. 2019, 55, 1258-1273. [CrossRef]

55. Korbee, N. Fotorregulación y Efecto del Nitrógeno Inorgánico en la Acumulación de Aminoácidos Tipo Micosporina en Algas Rojas. Ph.D. Thesis, University of Málaga, Málaga, Spain, 2003.

56. Hoyer, K.; Karsten, U.; Wiencke, C. Induction of sunscreen compounds in Antarctic macroalgae by different radiation conditions. Mar. Biol. 2002, 141, 619-627. [CrossRef]

57. Korbee, N.; Figueroa, F.L.; Aguilera, J. Effect of light quality on the accumulation of photosynthetic pigments, proteins and mycosporine-like amino acids in the red alga Porphyra leucosticta (Bangiales, Rhodophyta). J. Photochem. Photobiol. B Biol. 2005, 80, 71-78. [CrossRef] [PubMed]

58. Korbee, N.; Huovinen, P.; Figueroa, F.L.; Aguilera, J.; Karsten, U. Availability of ammonium influences photosynthesis and the accumulation of mycosporine-like amino acids in two Porphyra species (Bangiales, Rhodophyta). Mar. Biol. 2005, 146, 645-654. [CrossRef]

59. Navarro, N.P.; Figueroa, F.L.; Korbee, N. Mycosporine-like amino acids vs carrageenan yield in Mazzaella laminarioides (Gigartinales; Rhodophyta) under high and low UV solar irradiance. Phycologia 2017, 56, 570-578. [CrossRef]

60. Schneider, G.; Figueroa, F.L.; Vega, J.; Avilés, A.; Chaves, P.; Horta, P.A.; Korbee, N.; Bonomi-Barufi, J. Physiological and biochemical responses driven by different UV-visible radiation in: Osmundea pinnatifida (Hudson) Stackhouse (Rhodophyta). Photochem. Photobiol. Sci. 2020, 19, 1650-1664. [CrossRef]

61. Huovinen, P.; Matos, J.; Pinto, I.S.; Figueroa, F.L. The role of ammonium in photoprotection against high irradiance in the red alga Grateloupia lanceola. Aquat. Bot. 2006, 84, 308-316. [CrossRef]

62. Jiang, H.; Gao, K.; Helbling, E.W. UV-absorbing compounds in Porphyra haitanensis (Rhodophyta) with special reference to effects of desiccation. J. Appl. Phycol. 2008, 20, 387-395. [CrossRef]

63. Barufi, J.B.; Mata, M.T.; Oliveira, M.C.; Figueroa, F.L. Nitrate reduces the negative effect of UV radiation on photosynthesis and pigmentation in Gracilaria tenuistipitata (Rhodophyta): The photoprotection role of mycosporine-like amino acids. Phycologia 2012, 51, 636-648. [CrossRef]

64. Barufi, J.B.; Korbee-Peinado, N.; Oliveira, M.C.; Figueroa, F.L. Effects of N supply on the accumulation of photosynthetic pigments and photoprotectors in Gracilaria tenuistipitata (Rhodophyta) cultured under UV radiation. J. Appl. Phycol. 2011, 23, 457-466. [CrossRef]

65. Pliego-Cortés, H.; Bedoux, G.; Boulho, R.; Taupin, L.; Freile-Pelegrín, Y.; Bourgougnon, N.; Robledo, D. Stress tolerance and photoadaptation to solar radiation in Rhodymenia pseudopalmata (Rhodophyta) through mycosporine-like amino acids, phenolic compounds, and pigments in an Integrated Multi-Trophic Aquaculture system. Algal Res. 2019, 41, 101542. [CrossRef]

66. Jofre, J.; Celis-Plá, P.S.M.; Figueroa, F.L.; Navarro, N.P. Seasonal variation of mycosporine-like amino acids in three subantarctic red seaweeds. Mar. Drugs 2020, 18, 75. [CrossRef] [PubMed]

67. Bedoux, G.; Pliego-Cortés, H.; Dufau, C.; Hardouin, K.; Boulho, R.; Freile-Pelegrín, Y.; Robledo, D.; Bourgougnon, N. Production and properties of mycosporine-like amino acids isolated from seaweeds. Adv. Bot. Res. 2020, 95, 213-245. [CrossRef]

68. Karsten, U.; Bischof, K.; Hanelt, D.; Tüg, H.; Wiencke, C. The effect of ultraviolet radiation on photosynthesis and ultravioletabsorbing substances in the endemic Arctic macroalga Devaleraea ramentacea (Rhodophyta). Physiol. Plant. 1999, 105, 58-66. [CrossRef]

69. La Barre, S.; Roullier, C.; Boustie, J. Mycosporine-Like Amino Acids (MAAs) in Biological Photosystems. In Outstanding Marine Molecules; Wiley-VCH Verlag GmbH \& Co. KGaA: Weinheim, Germany, 2014; pp. 333-360.

70. Franklin, L.A.; Kräbs, G.; Kuhlenkamp, R. Blue light and UV-A radiation control the synthesis of mycosporine-like amino acids in Chondrus crispus (Florideophyceae). J. Phycol. 2001, 37, 257-270. [CrossRef]

71. Kräbs, G.; Bischof, K.; Hanelt, D.; Karsten, U.; Wiencke, C. Wavelength-dependent induction of UV-absorbing mycosporine-like amino acids in the red alga Chondrus crispus under natural solar radiation. J. Exp. Mar. Bio. Ecol. 2002, 268, 69-82. [CrossRef]

72. Torres, P.B.; Chow, F.; Ferreira, M.J.P.; dos Santos, D.Y.A.C. Mycosporine-like amino acids from Gracilariopsis tenuifrons (Gracilariales, Rhodophyta) and its variation under high light. J. Appl. Phycol. 2015, 28, 2035-2040. [CrossRef]

73. Bonomi-Barufi, J.; Figueroa, F.L.; Korbee, N.; Momoli, M.M.; Martins, A.P.; Colepicolo, P.; Van Sluys, M.A.; Oliveira, M.C. How macroalgae can deal with radiation variability and photoacclimation capacity: The example of Gracilaria tenuistipitata (Rhodophyta) in laboratory. Algal Res. 2020, 50, 102007. [CrossRef]

74. Korbee, N.; Figueroa, F.L.; Aguilera, J. Acumulación de aminoácidos tipo micosporina (MAAs): Biosíntesis, fotocontrol y funciones ecofisiológicas. Rev. Chil. Hist. Nat. 2006, 79, 119-132. [CrossRef]

75. Navarro, N.P.; Figueroa, F.L.; Korbee, N.; Mansilla, A.; Matsuhiro, B.; Barahona, T.; Plastino, E.M. The Effects of $\mathrm{NO}_{3}{ }^{-}$Supply on Mazzaella laminarioides (Rhodophyta, Gigartinales) from Southern Chile. Photochem. Photobiol. 2014, 90, 1299-1307. [CrossRef] [PubMed] 
76. Álvarez-Gómez, F.; Bouzon, Z.L.; Korbee, N.; Celis-Plá, P.; Schmidt, C.; Figueroa, F.L. Combined effects of UVR and nutrients on cell ultrastructure, photosynthesis and biochemistry in Gracilariopsis longissima (Gracilariales, Rhodophyta). Algal Res. 2017, 26, 190-202. [CrossRef]

77. Korbee-Peinado, N.; Abdala Díaz, R.T.; Figueroa, F.L.; Helbling, E.W. Ammonium and UV radiation stimulate the accumulation of mycosporine-like amino acids in Porphyra columbina (Rhodophyta) from Patagonia, Argentina. J. Phycol. 2004, 40, 248-259. [CrossRef]

78. Buschmann, A.H.; Camus, C.; Infante, J.; Neori, A.; Israel, Á.; Hernández-González, M.C.; Pereda, S.V.; Gomez-Pinchetti, J.L.; Golberg, A.; Tadmor-Shalev, N.; et al. Seaweed production: Overview of the global state of exploitation, farming and emerging research activity. Eur. J. Phycol. 2017, 52, 391-406. [CrossRef]

79. Food and Agriculture Organization of the United Nations (FAO). The State of World Fisheries and Aquaculture 2020; Food and Agriculture Organization of the United Nations (FAO): Quebec City, QC, Canada, 2020; ISBN 9789251326923.

80. Figueroa, F.L.; Bueno, A.; Korbee, N.; Santos, R.; Mata, L.; Schuenhoff, A. Accumulation of mycosporine-like amino acids in Asparagopsis armata grown in tanks with fishpond effluents of gilthead sea bream, Sparus aurata. J. World Aquac. Soc. 2008, 39, 692-699. [CrossRef]

81. Figueroa, F.L.; Korbee, N.; Abdala, R.; Jerez, C.G.; López-de la Torre, M.; Güenaga, L.; Larrubia, M.A.; Gómez-Pinchetti, J.L. Biofiltration of fishpond effluents and accumulation of $\mathrm{N}$-compounds (phycobiliproteins and mycosporine-like amino acids) versus C-compounds (polysaccharides) in Hydropuntia cornea (Rhodophyta). Mar. Pollut. Bull. 2012, 64, 310-318. [CrossRef] [PubMed]

82. Haroun, R.; Gil-Rodríguez, M.C.; Neto, A.I.; Machín-Sánchez, M.; Viera-Rodríguez, M.A. A review of current uses and potential biotechnological applications of seaweeds from the Macaronesian region (Central-East Atlantic Ocean). J. Appl. Phycol. 2019, 31, 3777-3790. [CrossRef]

83. Milledge, J.J.; Nielsen, B.V.; Bailey, D. High-value products from macroalgae: The potential uses of the invasive brown seaweed, Sargassum muticum. Rev. Environ. Sci. Bio Technol. 2016, 15, 67-88. [CrossRef]

84. Stabili, L.; Fraschetti, S.; Acquaviva, M.; Cavallo, R.; De Pascali, S.; Fanizzi, F.; Gerardi, C.; Narracci, M.; Rizzo, L. The Potential Exploitation of the Mediterranean Invasive Alga Caulerpa cylindracea: Can the Invasion Be Transformed into a Gain? Mar. Drugs 2016, 14, 210. [CrossRef]

85. Pinteus, S.; Lemos, M.F.L.; Alves, C.; Neugebauer, A.; Silva, J.; Thomas, O.P.; Botana, L.M.; Gaspar, H.; Pedrosa, R. Marine invasive macroalgae: Turning a real threat into a major opportunity-The biotechnological potential of Sargassum muticum and Asparagopsis armata. Algal Res. 2018, 34, 217-234. [CrossRef]

86. Félix, R.; Carmona, A.M.; Félix, C.; Novais, S.C.; Lemos, M.F.L. Industry-Friendly Hydroethanolic Extraction Protocols for Grateloupia turuturu UV-Shielding and Antioxidant Compounds. Appl. Sci. 2020, 10, 5304. [CrossRef]

87. Pereira, A.G.; Fraga-Corral, M.; Garcia-Oliveira, P.; Lourenço-Lopes, C.; Carpena, M.; Prieto, M.A.; Simal-Gandara, J. The Use of Invasive Algae Species as a Source of Secondary Metabolites and Biological Activities: Spain as Case-Study. Mar. Drugs 2021, 19, 178. [CrossRef]

88. Desrochers, A.; Cox, S.; Oxenford, H.; Van Tussenbroek, B. Sargassum Uses Guide: A Resource for Caribbean Researchers, Entrepreneurs and Policy Makers Lead; Food and Agriculture Organization of the United Nations: Quebec City, QC, Canada, 2020 ; p. 100.

89. Tartarotti, B.; Sommaruga, R. The effect of different methanol concentrations and temperatures on the extraction of mycosporinelike amino acids (MAAs) in algae and zooplankton. Arch. Hydrobiol. 2002, 154, 691-703. [CrossRef]

90. Carreto, J.I.; Carignan, M.O.; Montoya, N.G. A high-resolution reverse-phase liquid chromatography method for the analysis of mycosporine-like amino acids (MAAs) in marine organisms. Mar. Biol. 2005, 146, 237-252. [CrossRef]

91. Bois, F.Y.; Ochoa, J.G.D.; Gajewska, M.; Kovarich, S.; Mauch, K.; Paini, A.; Péry, A.; Benito, J.V.S.; Teng, S.; Worth, A. Multiscale modelling approaches for assessing cosmetic ingredients safety. Toxicology 2017, 392, 130-139. [CrossRef] [PubMed]

92. Zainal-Abidin, M.H.; Hayyan, M.; Hayyan, A.; Jayakumar, N.S. New horizons in the extraction of bioactive compounds using deep eutectic solvents: A review. Anal. Chim. Acta 2017, 979, 1-23. [CrossRef]

93. Welton, T. Solvents and sustainable chemistry. Proc. R. Soc. A Math. Phys. Eng. Sci. 2015, 471, 1-26. [CrossRef] [PubMed]

94. Kadam, S.U.; Tiwari, B.K.; O'Donnell, C.P. Application of novel extraction technologies for bioactives from marine algae. J. Agric. Food Chem. 2013, 61, 4667-4675. [CrossRef]

95. Michalak, I.; Chojnacka, K. Algae as production systems of bioactive compounds. Eng. Life Sci. 2015, 15, 160-176. [CrossRef]

96. Cikoš, A.-M.; Jokić, S.; Šubarić, D.; Jerković, I. Overview on the Application of Modern Methods for the Extraction of Bioactive Compounds from Marine Macroalgae. Mar. Drugs 2018, 16, 348. [CrossRef] [PubMed]

97. Heo, S.J.; Park, E.J.; Lee, K.W.; Jeon, Y.J. Antioxidant activities of enzymatic extracts from brown seaweeds. Bioresour. Technol. 2005, 96, 1613-1623. [CrossRef]

98. Wang, T.; Jónsdóttir, R.; Kristinsson, H.G.; Hreggvidsson, G.O.; Jónsson, J.Ó.; Thorkelsson, G.; Ólafsdóttir, G. Enzyme-enhanced extraction of antioxidant ingredients from red algae Palmaria palmata. LWT Food Sci. Technol. 2010, 43, 1387-1393. [CrossRef]

99. Rodrigues, D.; Sousa, S.; Silva, A.; Amorim, M.; Pereira, L.; Rocha-Santos, T.A.P.; Gomes, A.M.P.; Duarte, A.C.; Freitas, A.C. Impact of enzyme- and ultrasound-assisted extraction methods on biological properties of red, brown, and green seaweeds from the Central West Coast of Portugal. J. Agric. Food Chem. 2015, 63, 3177-3188. [CrossRef] [PubMed]

100. Mittal, R.; Raghavarao, K.S.M.S. Extraction of R-Phycoerythrin from marine macro-algae, Gelidium pusillum, employing consortia of enzymes. Algal Res. 2018, 34, 1-11. [CrossRef] 
101. Pliego-Cortés, H.; Wijesekara, I.; Lang, M.; Bourgougnon, N.; Bedoux, G. Current knowledge and challenges in extraction, characterization and bioactivity of seaweed protein and seaweed-derived proteins. Adv. Bot. Res. 2020, 95, 289-326. [CrossRef]

102. Nguyen, T.T.; Mikkelsen, M.D.; Tran, V.H.N.; Trang, V.T.D.; Rhein-Knudsen, N.; Holck, J.; Rasin, A.B.; Cao, H.T.T.; Van, T.T.T.; Meyer, A.S. Enzyme-Assisted Fucoidan Extraction from Brown Macroalgae Fucus distichus subsp. evanescens and Saccharina latissima. Mar. Drugs 2020, 18, 296. [CrossRef] [PubMed]

103. Mittal, R.; Tavanandi, H.A.; Mantri, V.A.; Raghavarao, K.S.M.S. Ultrasound assisted methods for enhanced extraction of phycobiliproteins from marine macro-algae, Gelidium pusillum (Rhodophyta). Ultrason. Sonochem. 2017, 38, 92-103. [CrossRef] [PubMed]

104. Kumar, Y.; Singhal, S.; Tarafdar, A.; Pharande, A.; Ganesan, M.; Badgujar, P.C. Ultrasound assisted extraction of selected edible macroalgae: Effect on antioxidant activity and quantitative assessment of polyphenols by liquid chromatography with tandem mass spectrometry (LC-MS/MS). Algal Res. 2020, 52, 102114. [CrossRef]

105. Ren, B.; Chen, C.; Li, C.; Fu, X.; You, L.; Liu, R.H. Optimization of microwave-assisted extraction of Sargassum thunbergii polysaccharides and its antioxidant and hypoglycemic activities. Carbohydr. Polym. 2017, 173, 192-201. [CrossRef] [PubMed]

106. Yuan, Y.; Zhang, J.; Fan, J.; Clark, J.; Shen, P.; Li, Y.; Zhang, C. Microwave assisted extraction of phenolic compounds from four economic brown macroalgae species and evaluation of their antioxidant activities and inhibitory effects on $\alpha$-amylase, $\alpha$-glucosidase, pancreatic lipase and tyrosinase. Food Res. Int. 2018, 113, 288-297. [CrossRef]

107. Grosso, C.; Valentão, P.; Ferreres, F.; Andrade, P. Alternative and Efficient Extraction Methods for Marine-Derived Compounds. Mar. Drugs 2015, 13, 3182-3230. [CrossRef]

108. Meillisa, A.; Siahaan, E.A.; Park, J.N.; Woo, H.C.; Chun, B.S. Effect of subcritical water hydrolysate in the brown seaweed Saccharina japonica as a potential antibacterial agent on food-borne pathogens. J. Appl. Phycol. 2013, 25, 763-769. [CrossRef]

109. Ahmadian-Kouchaksaraie, Z.; Niazmand, R.; Najafi, M.N. Optimization of the subcritical water extraction of phenolic antioxidants from Crocus sativus petals of saffron industry residues: Box-Behnken design and principal component analysis. Innov. Food Sci. Emerg. Technol. 2016, 36, 234-244. [CrossRef]

110. Saravana, P.S.; Tilahun, A.; Gerenew, C.; Tri, V.D.; Kim, N.H.; Kim, G.D.; Woo, H.C.; Chun, B.S. Subcritical water extraction of fucoidan from Saccharina japonica: Optimization, characterization and biological studies. J. Appl. Phycol. 2018, 30, 579-590. [CrossRef]

111. Chemat, F.; Vian, M.A.; Ravi, H.K.; Khadhraoui, B.; Hilali, S.; Perino, S.; Tixier, A.S.F. Review of Alternative Solvents for Green Extraction of Food and Natural Products: Panorama, Principles, Applications and Prospects. Molecules 2019, 24, 3007. [CrossRef]

112. Nakamura, H.; Kobayashi, J.; Hirata, Y. Separation of mycosporine-like amino acids in marine organisms using reversed-phase high-performance liquid chromatography. J. Chromatogr. A 1982, 250, 113-118. [CrossRef]

113. Dunlap, W.C.; Chalker, B.E. Identification and quantitation of near-UV absorbing compounds (S-320) in a hermatypic scleractinian. Coral Reefs 1986, 5, 155-159. [CrossRef]

114. Stochaj, W.R.; Dunlap, W.C.; Shick, J.M. Two new UV-absorbing mycosporine-like amino acids from the sea anemone Anthopleura elegantissima and the effects of zooxanthellae and spectral irradiance on chemical composition and content. Mar. Biol. 1994, 118, 149-156. [CrossRef]

115. Helbling, E.W.; Chalker, B.E.; Dunlap, W.C.; Holm-Hansen, O.; Villafañe, V.E. Photoacclimation of antarctic marine diatoms to solar ultraviolet radiation. J. Exp. Mar. Bio. Ecol. 1996, 204, 85-101. [CrossRef]

116. Carreto, J.; Carignan, M.; Montoya, N. Comparative studies on mycosporine-like amino acids, paralytic shellfish toxins and pigment profiles of the toxic dinoflagellates Alexandrium tamarense, A. catenella and A. minutum. Mar. Ecol. Prog. Ser. 2001, 223, 49-60. [CrossRef]

117. Alvarez-Rivera, G.; Bueno, M.; Ballesteros-Vivas, D.; Mendiola, J.A.; Ibañez, E. Pressurized liquid extraction. In Liquid-Phase Extraction; Poole, C.F., Ed.; Elsevier: Amsterdam, The Netherlands, 2019; pp. 375-398, ISBN 9780128169117.

118. Hartmann, A.; Becker, K.; Karsten, U.; Remias, D.; Ganzera, M. Analysis of mycosporine-like amino acids in selected algae and cyanobacteria by hydrophilic interaction liquid chromatography and a novel MAA from the red alga Catenella repens. Mar. Drugs 2015, 13, 6291-6305. [CrossRef] [PubMed]

119. Nishida, Y.; Kumagai, Y.; Michiba, S.; Yasui, H.; Kishimura, H. Efficient Extraction and Antioxidant Capacity of Mycosporine-Like Amino Acids from Red Alga Dulse Palmaria palmata in Japan. Mar. Drugs 2020, 18, 502. [CrossRef]

120. Geraldes, V.; de Medeiros, L.S.; Jacinavicius, F.R.; Long, P.F.; Pinto, E. Development and validation of a rapid LC-MS/MS method for the quantification of mycosporines and mycosporine-like amino acids (MAAs) from cyanobacteria. Algal Res. 2020, 46,101796 [CrossRef]

121. Chaves-Peña, P.; De La Coba, F.; Figueroa, F.L.; Korbee, N. Quantitative and qualitative HPLC analysis of mycosporine-like amino acids extracted in distilled water for cosmetical uses in four Rhodophyta. Mar. Drugs 2020, 18, 27. [CrossRef]

122. Orfanoudaki, M.; Hartmann, A.; Karsten, U.; Ganzera, M. Chemical profiling of mycosporine-like amino acids in twenty-three red algal species. J. Phycol. 2019, 55, 393-403. [CrossRef]

123. Ryu, J.; Park, S.J.; Kim, I.H.; Choi, Y.H.; Nam, T.J. Protective effect of porphyra-334 on UVA-induced photoaging in human skin fibroblasts. Int. J. Mol. Med. 2014, 34, 796-803. [CrossRef] [PubMed]

124. Rastogi, R.P.; Incharoensakdi, A. UV radiation-induced biosynthesis, stability and antioxidant activity of mycosporine-like amino acids (MAAs) in a unicellular cyanobacterium Gloeocapsa sp. CU2556. J. Photochem. Photobiol. B Biol. 2014, 130, 287-292. [CrossRef] [PubMed] 
125. Yuan, Y.V.; Westcott, N.D.; Hu, C.; Kitts, D.D. Mycosporine-like amino acid composition of the edible red alga, Palmaria palmata (dulse) harvested from the west and east coasts of Grand Manan Island, New Brunswick. Food Chem. 2009, 112, 321-328. [CrossRef]

126. Karsten, U.; Escoubeyrou, K.; Charles, F. The effect of re-dissolution solvents and HPLC columns on the analysis of mycosporinelike amino acids in the eulittoral macroalgae Prasiola crispa and Porphyra umbilicalis. Helgol. Mar. Res. 2009, 63, 231-238. [CrossRef]

127. De La Coba, F.; Aguilera, J.; Figueroa, F.L.; De Gálvez, M.V.; Herrera, E. Antioxidant activity of mycosporine-like amino acids isolated from three red macroalgae and one marine lichen. J. Appl. Phycol. 2009, 21, 161-169. [CrossRef]

128. Torres, A.; Enk, C.D.; Hochberg, M.; Srebnik, M. Porphyra-334, a potential natural source for UVA protective sunscreens. Photochem. Photobiol. Sci. 2006, 5, 432-435. [CrossRef]

129. Cardozo, K.H.M.; Carvalho, V.M.; Pinto, E.; Colepicolo, P. Fragmentation of mycosporine-like amino acids by hydrogen/deuterium exchange and electrospray ionisation tandem mass spectrometry. Rapid Commun. Mass Spectrom. 2006, 20, 253-258. [CrossRef] [PubMed]

130. Sinha, R.P.; Klisch, M.; Gröniger, A.; Häder, D.P. Mycosporine-like amino acids in the marine red alga Gracilaria cornea-Effects of UV and heat. Environ. Exp. Bot. 2000, 43, 33-43. [CrossRef]

131. Karsten, U.; Franklin, L.A.; Tüning, K.; Wiencke, C. Natural ultraviolet radiation and photosynthetically active radiation induce formation of mycosporine-like amino acids in the marine macroalga Chondrus crispus (Rhodophyta). Planta 1998, 205, 257-262. [CrossRef]

132. Rój, E.; Dobrzyńska-Inger, A.; Dębczak, A.; Kostrzewa, D.; Stępnik, K. Algae Extract Production Methods and Process Optimization. In Marine Algae Extracts; Kim, S.-K., Chojnacka, K., Eds.; Wiley: Hoboken, NJ, USA, 2015; Volume 1-2, pp. 101-120.

133. Byrne, F.P.; Jin, S.; Paggiola, G.; Petchey, T.H.M.; Clark, J.H.; Farmer, T.J.; Hunt, A.J.; Robert McElroy, C.; Sherwood, J. Tools and techniques for solvent selection: Green solvent selection guides. Sustain. Chem. Process. 2016, 4, 1-24. [CrossRef]

134. Dembek, M.; Bocian, S. Pure water as a mobile phase in liquid chromatography techniques. TrAC Trends Anal. Chem. 2020, 123, 115793. [CrossRef]

135. Roullier, C.; Chollet-Krugler, M.; Bernard, A.; Boustie, J. Multiple dual-mode centrifugal partition chromatography as an efficient method for the purification of a mycosporine from a crude methanolic extract of Lichina pygmaea. J. Chromatogr. B Anal. Technol. Biomed. Life Sci. 2009, 877, 2067-2073. [CrossRef]

136. Boulho, R.; Le Roux, J.; Le Quémener, C.; Audo, G.; Bourgougnon, N.; Bedoux, G. Fractionation of UV-B absorbing molecules and of free radical scavenging compounds from Solieria chordalis by using centrifugal partition chromatography. Phytochem. Lett. 2017, 20, 410-414. [CrossRef]

137. Latif, Z.; Sarker, S.D. Isolation of natural products by preparative high performance liquid chromatography (Prep-HPLC). Methods Mol. Biol. 2012, 864, 255-274. [CrossRef]

138. DeAmicis, C.; Edwards, N.A.; Giles, M.B.; Harris, G.H.; Hewitson, P.; Janaway, L.; Ignatova, S. Comparison of preparative reversed phase liquid chromatography and countercurrent chromatography for the kilogram scale purification of crude spinetoram insecticide. J. Chromatogr. A 2011, 1218, 6122-6127. [CrossRef] [PubMed]

139. Michel, T.; Destandau, E.; Elfakir, C. New advances in countercurrent chromatography and centrifugal partition chromatography: Focus on coupling strategy. Anal. Bioanal. Chem. 2014, 406, 957-969. [CrossRef] [PubMed]

140. Kageyama, H.; Waditee-Sirisattha, R. Antioxidative, anti-inflammatory, and anti-aging properties of mycosporine-like amino acids: Molecular and cellular mechanisms in the protection of skin-aging. Mar. Drugs 2019, 17, 222. [CrossRef]

141. Rosic, N. Mycosporine-Like Amino Acids: Making the Foundation for Organic Personalised Sunscreens. Mar. Drugs 2019, 17, 638. [CrossRef]

142. Dunlap, W.C.; Yamamoto, Y. Small-molecule antioxidants in marine organisms: Antioxidant activity of mycosporine-glycine. Comp. Biochem. Physiol. Part B Biochem. 1995, 112, 105-114. [CrossRef]

143. Torres, P.; Santos, J.P.; Chow, F.; Pena Ferreira, M.J.; dos Santos, D.Y.A.C. Comparative analysis of in vitro antioxidant capacities of mycosporine-like amino acids (MAAs). Algal Res. 2018, 34, 57-67. [CrossRef]

144. Wang, H.M.D.; Li, X.C.; Lee, D.J.; Chang, J.S. Potential biomedical applications of marine algae. Bioresour. Technol. 2017, 244, 1407-1415. [CrossRef] [PubMed]

145. Hartmann, A.; Gostner, J.; Fuchs, J.E.; Chaita, E.; Aligiannis, N.; Skaltsounis, L.; Ganzera, M. Inhibition of collagenase by mycosporine-like amino acids from marine sources. Planta Med. 2015, 81, 813. [CrossRef] [PubMed]

146. Orfanoudaki, M.; Hartmann, A.; Alilou, M.; Gelbrich, T.; Planchenault, P.; Derbré, S.; Schinkovitz, A.; Richomme, P.; Hensel, A.; Ganzera, M. Absolute Configuration of Mycosporine-Like Amino Acids, Their Wound Healing Properties and In Vitro Anti-Aging Effects. Mar. Drugs 2019, 18, 35. [CrossRef]

147. Suh, S.-S.; Hwang, J.; Park, M.; Seo, H.; Kim, H.-S.; Lee, J.; Moh, S.; Lee, T.-K. Anti-Inflammation Activities of Mycosporine-Like Amino Acids (MAAs) in Response to UV Radiation Suggest Potential Anti-Skin Aging Activity. Mar. Drugs 2014, 12, 5174-5187. [CrossRef]

148. Becker, K.; Hartmann, A.; Ganzera, M.; Fuchs, D.; Gostner, J. Immunomodulatory Effects of the Mycosporine-Like Amino Acids Shinorine and Porphyra-334. Mar. Drugs 2016, 14, 119. [CrossRef] 
149. De la Coba, F.; Aguilera, J.; Korbee, N.; de Gálvez, M.V.; Herrera-Ceballos, E.; Álvarez-Gómez, F.; Figueroa, F.L. UVA and UVB Photoprotective capabilities of topical formulations containing mycosporine-like amino acids (maas) through different biological effective protection factors (BEPFs). Mar. Drugs 2019, 17, 55. [CrossRef] [PubMed]

150. Álvarez-Gómez, F.; Korbee, N.; Casas-Arrojo, V.; Abdala-Díaz, R.T.; Figueroa, F.L. UV photoprotection, cytotoxicity and immunology capacity of red algae extracts. Molecules 2019, 24, 341. [CrossRef]

151. De la Coba, F.; Aguilera, J.; de Gálvez, M.V.; Álvarez, M.; Gallego, E.; Figueroa, F.L.; Herrera, E. Prevention of the ultraviolet effects on clinical and histopathological changes, as well as the heat shock protein-70 expression in mouse skin by topical application of algal UV-absorbing compounds. J. Dermatol. Sci. 2009, 55, 161-169. [CrossRef] [PubMed]

152. Mercurio, D.G.; Wagemaker, T.A.L.; Alves, V.M.; Benevenuto, C.G.; Gaspar, L.R.; Maia Campos, P.M.B.G. In vivo photoprotective effects of cosmetic formulations containing UV filters, vitamins, Ginkgo biloba and red algae extracts. J. Photochem. Photobiol. B Biol. 2015, 153, 121-126. [CrossRef]

153. Ying, R.; Zhang, Z.; Zhu, H.; Li, B.; Hou, H. The Protective Effect of Mycosporine-Like Amino Acids (MAAs) from Porphyra yezoensis in a Mouse Model of UV Irradiation-Induced Photoaging. Mar. Drugs 2019, 17, 470. [CrossRef] [PubMed]

154. Lawrence, K.P.; Gacesa, R.; Long, P.F.; Young, A.R. Molecular photoprotection of human keratinocytes in vitro by the naturally occurring mycosporine-like amino acid palythine. Br. J. Dermatol. 2018, 178, 1353-1363. [CrossRef] [PubMed]

155. Rui, Y.; Zhaohui, Z.; Wenshan, S.; Bafang, L.; Hu, H. Protective effect of MAAs extracted from Porphyra tenera against UV irradiation-induced photoaging in mouse skin. J. Photochem. Photobiol. B Biol. 2019, 192, 26-33. [CrossRef]

156. Figueroa, F.L. Mycosporine-Like Amino Acids from Marine Resource. In Marine Drugs; MPDI: Basel, Switzerland, 2021; Volume 171, ISBN 978-3-0365-0325-75.

157. Pangestuti, R.; Shin, K.-H.; Kim, S.-K. Anti-photoaging and potential skin health benefits of seaweeds. Marine Drugs 2021, $19,172$. [CrossRef] [PubMed] 